\title{
Cell Kinetics of the Oral Epithelium of Adrenalectomized and of Hypophysectomized Mice
}

\author{
Elliott Howard Dickler \\ Loyola University Chicago
}

Follow this and additional works at: https://ecommons.luc.edu/luc_theses

Part of the Medicine and Health Sciences Commons

\section{Recommended Citation}

Dickler, Elliott Howard, "Cell Kinetics of the Oral Epithelium of Adrenalectomized and of Hypophysectomized Mice" (1968). Master's Theses. 2261.

https://ecommons.luc.edu/luc_theses/2261

This Thesis is brought to you for free and open access by the Theses and Dissertations at Loyola eCommons. It has been accepted for inclusion in Master's Theses by an authorized administrator of Loyola eCommons. For more information, please contact ecommons@luc.edu. c) (i) (9)

This work is licensed under a Creative Commons Attribution-Noncommercial-No Derivative Works 3.0 License. Copyright (C) 1968 Elliott Howard Dickler 
CELL KIMETICS OF THE ORAL EPITAELTOY OF AOREMLECTOMIZED AND OF HYPOHAYSECTOMCZED MICE

by

EIliott Howard DHoklor

1 Thesle subutted to the Faoulty of the Graduato Sohool of Ioyola Univeratt in Partial Mulfillant of the Requiremente for the Degree of Mastor of Solenee

Jano

1968 
I dediente this theols to ay wfo Phyllis, wose conotant undorstanding and oncourageaent wade this work posstble. 


\section{ACKNOWLEDGEMENTS}

The author wises to thank Dr. Anthony W. Gargiulo for his guidance and pereonal interest in this work.

The author wishes to express his sincore appreciation and gretitude to Dr. Patrick D. Toto wose infinito pationoe and constant advioe and enoouragement made this thesis posatble. 


\section{LIFE}

Elllott Howard Dickler was born in Beltimore, Meryland, October 16. 1931.

He wes eduoated in the Beltimore fublte Sehools whore he we graduated from Foreat Park H1gh Sohool in 1949. The next four years he attonded the Univerefty of Maryland and recelved his Bachelor of Solence degreo in 1953. He then entered the Baltimore Colloge of Dental surgery. Unireratty of Maryland. In June 1957 be was graduated with the degree of Dootor of Dental surgery.

In September 1966, he onrolled in the Oral Blology Greduate Progran of Loyola Univeralty Sohool of Dontistry in Chioago. IIIInols. 


\section{TABLE OF COMTENS}

CHAPTER

I. Introduction

1.

II. Revien of itterature

2

III. Materials and Methods

IV. Findings

v. DLscussion

24

VI. Sumany

30

VII. Conalustons

32

VIII. Bibltograply

34

IX. Tables

38

X. Figures

46 


\section{IITRODUCTION}

Recent investigations have show that a significant change occurs in the mitotic rate and cell turnover of epidermis when animals are subjected to deprivations of hormones from the pituitary gland and from the adrenal glands (Bachntk, 1966; Bullough, 1949; Bullough and Laurence, 1959 and 1961; Chaudhry and Halberg, 1956 and 1961). Studies have also been made upon the rate of cell turnover of oral epithelium of interdental papilla in the normal mouse (Joglekar, 1964) and the ovariactomized mouse (Bachnik, 1966).

The effects of adrenalectomy and of hypophysectomy upon the cell kinetics and desoxyribose nucleic acid doubling time of the oral epithelium of the mouse have not been investigated. This study was limited to an investigation of these hormone deficlencies upon the oral squamous epithelium of the interdental papilla and the attached epithelfum.

Using tritlated thymidine to label the cells preparing for mitosis, cell counts were used to determine doubling time of oral epithelial cells of the interdental papilla between the mandibular first and second molar of the mouse. The lack of hormones in adrenalectory and hypophysectony may significantly change the rate of DNA synthesis, hence change the rate of cell renewal and cell migration. 


\section{REVIEW OF LTTERATURE}

Control of Mitoris

The mitotio activity is subjoctad to control. from various soures ouch aoting as a belenelng force toward the other. These controls have been udely Invertigated as to thelr exeot mature and mode of action. Ziskind. Dan1el. and Blackborg (1940) using hypophysoetomized and oastrated rhesus monkey: roported degenerative changes woh as 1080 of koratin, poorly prem sorred Intoreallular bridgos, and euperfletal opldorwal layore adeatng. They found no afgnifloant changes in ressels. Inflamatory rosponse or at to sts to acoount for then, and the oridenese of thatue degenoration more moro earked in the hypophjesotondsed group as a whole than is the fomalo oatrate group.

Bullough (1949 a), naling wale wee, found that an inorease in blood argar vie subeutencous otaroh infections oaueod an inoroased at totic rato In the epthollue of the esophagus and sallvary glands. He also states that the attotio rate is deoreaced by lowering the blood agar level with inculin. He explaine this apparont contradiotion by concluding that the oritioal factor in the control of altotio ojeles 1 s the oonoentretion of mgar in the themes themeelres, bocause the diurmal obanges in blood sugar are the reveree of those for mitotio ectivity. 1.e.. that blood ougar per so is not the aruatal factor wioh dotormines the form of the diumal ojolos. The sotual control would appear to be exerolsed by come finor moohantev which is only arudely affected by unnaturally great ahanges in blood ougar coneentration. 
He hypothedises that the mitoses (noeding augar to onorgise the process) takes pleos most actirely when sugar is doposited from the blood into the therues and e elear understanding of the fectors controlling such dopostion 1. nocessary to explatin the variations in eitotio ratos. Again Bullough (1949 b) otates that It appears that ougar 1s the vital factor involved. and that the sugar content of tisoves 1s used up quilokly during high altotio activity. In 1952 (a) Bullough stated that the feotors which offeot witods oan be roughly divided into hormonal and nutritional but at least sowe of their sotion is by intorforence in carbohydrate motaboliza. ". . ith direct mitogenie hormones exeepted, one of the most reankable conoluations to be dram from these obeorvations is the reletive unimportance of any factor othor than that of carbohydrate amply and utilisation."

Lator in 1952 (b). Bullough also found that atotlo activity is doprosed by stress attuations. Ho found groutly Inoresead adrenal gland adse In saoh stressed animals. The prosumption 1s that the increase in 1ts alse 1s ecoompanted by an excosedve scorettion of edrenalln from the medulls and gluevoorticolds from the cortex, and furtherwore that the intotie depresection was the result of these homones. The medullary hypertrophy was unexpected Ance it doos not hypertrophy after unilatoral adrenaleotomy and aince it wes thought to play an active part only during the first fou minutes of atress (Selye, 1950). Adrenulin action through the anterior pituttery produotion of ACTH, Induces seoretion of glucooorticold hormones from the adrenals. Thus, secording to Bullough, the antiaftotio sotivity of adream alin way be due to cortl cone-like mbstances. 
ro furthor desoribe the rystem of interdopondence and Intorrelationships of the various altotic controls. Best (1952) quoting Kostor (1930), and Griffiths (1941), states that hypophyseotony oreates atrophy of the actinar tissue of the panoras thus inoreasing the ratio of ialot tissue to acinar tissue in hypophysectomised rats oven though the islet tisoue has not incrased in amount.

The intotio oontrol of the pitultary growth hormone is really axerted by settion on the panorvas. as ahown by Young (1953) and Bullough (1954). Their works acoept the dependence of epiderwal mitotie sotivity in aice on the rate of glucose entry into the cells and 1ts transformation into energo. Bullough (1954) further states that inculln Incroaces the number of adtoses wile growth hormone acts as in inhibitor." Whon introduced togethor

\section{*ill togenio Effoot of Insurin in V1tro Subutratem-0.02M Gluosese}

\begin{tabular}{|c|c|c|c|c|c|}
\hline $\begin{array}{l}\text { Mitosi: } \\
\text { Reoorded by } \\
\text { Colohielno }\end{array}$ & $\begin{array}{l}\text { Alone } \\
9.1 \\
\pm .52\end{array}$ & $\begin{array}{l}0.50 \\
\text { Insul. } \\
14.3 \\
\pm 1.19\end{array}$ & $\begin{array}{c}54 \\
\text { Insul. } \\
17.7 \\
\pm .96\end{array}$ & $\begin{array}{l}504 \\
\text { Insul. } \\
18.7 \\
\pm .8\end{array}$ & $\begin{array}{l}250 \mathrm{u} \\
\text { Insul. } \\
17.0 \\
\pm \quad .89\end{array}$ \\
\hline
\end{tabular}

Bullough hypothestses the Influenoe of insulin to be wolly due to epeeding the reaction: Glucoes $\rightarrow$ GIuoose -6 - phoophate on the cell will, they counteraet ach other. The axistenes of soparate fractions in pitultery hormone, one of grouth horwone and one of diabotogenle nature as suggested by Raben and Wentermayor (1952). 1s not corroborated by roung (1953). Tho parifled hormone desoribed by Cotes, Ried, and Young (1949) has both growth and diabotogente raotors. 


\section{5}

The direot action of the pituttary horwone upon the panoreas 1 s beat dosortbed in the work of Rlohardeon and Young (1939), Krloheoky (1936), and Marks and Young (1939). Thelr ovidenos indicates that pltuitary grouth hormone oavses timalation to 1slet thene of panoreas. Marks and Young roported buge increases in the amount of insulin in the panorwas of axpors Inontal anials aftor two woks of datly treatmont with orude antorior pitudtary extract. This increase we in the order of $1304-2505_{3}$ howerer. no imadiate roport of its affect on adtogls was given.

Bullough (1952 a) theorises that thore are two wain ditoolemoontrolling forees. the swo of the effects of the extarnal hormonal oontrole being only one of these foroes. This is the moro mperflotal, eastly analysed and is responstble for the diumel (hour-tomour and day-tomay) oroles. The seoond Altosis-control foree is apparently inherent in the speoles of tieme, wioh he ealls "ohalene." beoause tholr primary nmotion is to slow growth.

The idtotie rates of raploas tissues at any given moment seam to bo detarmined by two matn groups of factors. The flrot group contains a numbor of hormones w th direet relationships on oells proparing for witosts. The second group evidently ineludes a large number of thasue-upeeiflo substanees the natare of which is largely unknown, but whioh are posedbly protelns (Bullough, 2962). He states further that thore appears to be only one of thoes rabstances produoed by each theres and that it reeets on that ane

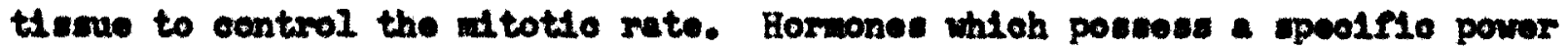
to inhibit adtoves are gluoocortioolds and adronalin, and the altotio rato 
may rise greatly after either hypophysectomy or adrenelectomy. However, both of these hormones inhtbit mitosis more powerfully in some tissues, such as growing hair bulbs. Therefore, it is clear that their action is more tissue-specific than mitosis-speciflo (Bullough, 1962). Furthermore, the evidence shows that while mitotic rate of tissues may be influenced by hormones, it is not controlled by them. The ultimate control of mitotic rate evidently resides within the tissues themselves, and in appropriate circumstances the cells of most tissues are capable of indefint to growth and witosis; each tissue-speciflc control mechanism must be anti-mitotic. Since the primary function of these anti-mitotic control substances is to slow growth, the name Chalone is more appropriate than Hormone (Bullough. 1962).

The diurnal oycles are the result of fluctuations in the supply of essential nutrients (carbohydrate in the form of glucose). When carbohydrates are available, mitotio rate rises steoply. Conversely, when carbohydrates are eliminated and fall to reach the tissues, the mitotic activity ceases. Therefore, high mitotic activity is typlcal of well-fed resting animals and low mitotic activity 18 typion of starved animals at hard work (Bullough, 1955). Corl (1950) states that cortain hormones, adronalln and Insulin, can affoct rate-limiting reactions in carbohydrate motabolism. In the case of mamalian epidermis, the suggestion has already been made that af totic rate may vary directly whth the degree of activity of the enzyme glucokinase, and further this ensyme is susceptible to hormone influence. Cort (1950) in an address to the flrst International Congress of Btochemistry, Indicated one hormone, insulin, which stimulates the glucokinase 


\section{7}

syatem and two horwonee, pitultary grouth hormone and adrenal gluocoortileotd hormone which Inhibit it. Corl oonfirns that grouth horwone antagonises inoulen by inhibiting the gluooldnase reastion. Bullough tasted this in Atro in 1954 using gluoose substrate, and found growth hormone to be a atotie inhibitor "although it is orident that relatively large dowes aro required to produce anj great effeot" (results on page four). He states (that) the fact that pitultary grouth hormone prevents dovelopment of altotle activity is wo mupriaing that further consideration wa nocoscary. The augestion by Rabdn and Westernoyor (1952). that the hormone extreots ware not pure, but contaninated by a scoond hormone olosely dud lar ohemically. wa disproved by Young (1953). Bullough (1955) contimues. "the alternative theory mat be exandned, that growth hormone is Indeed an Inhibitar of oarbohydrate notabolle and therofore of idtotio cotidity of suoh thesues as opldornds. . . It has boes suggonted that in normel ofrcunstances a hlgh rate of grouth hormone scorotion is oountored by a high rate of invalin scarvtion, and that ingulin is in fact the real growth hormone." Thorafore, atrong ase can be ande In favor of grouth promotion by Insulin secroted in response to growth horwone stimulation. As stated another may. Toung (1953), quoting his 1940 work roports, ". . grouth promoting cotion of antarior lobe axtreots way be oontingent upon the ability of the panoreas to seorete weflolent inculten to induee nitrogen rotention and promoto carbohydrate oxidation." Toung coneludos that in youth the

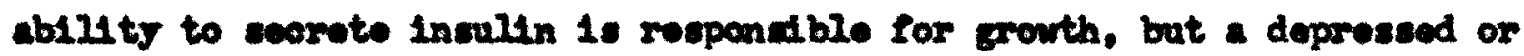
loot ability of the panoreas to elaborate inmulin, as in an adult, results 
in diabotos. Best (1952) showed this to be true by injooting insulin into hpophysetontzed younz rats, and they grov to adult sizo. Bullough (1955) furthor states that adranaln plus adronochoro, both act in Elucose notaboliss in one or moro of nany blochemiod roctions. Moroovor, "the value of adramitin soorotion in an enorgancy must, therofore, romin in bone soubt. The glueoso raloased fran the liva in tho blood annot bo roadity taken up and utilyod and ovidenty the strulus to he nuselor is mainly If not wholly concornad with glycolysts."

The action of ACII and rlucocortscota homones is one of nodarate stinulation, and cortisone one of depresston of ntosis (not at the Blicolenase love1). Swamn (1958). Bullough (1955) conoludes that hormones

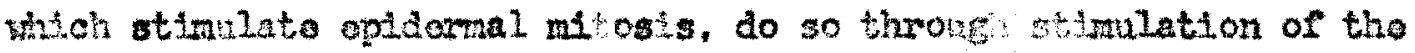
glucolinaso systan. Bramplos aro insulin, astrozons, wak astrogento starods, and possibly a contantinent of ACH.

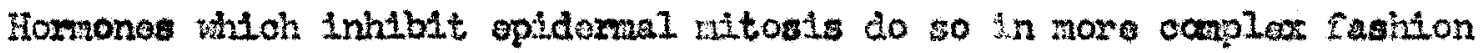
Interforine in a number of potnts, one of which :ay bo the glucoldnaso systar. It appoars to bo natural punction of all calls to grow, and divdo, and tho fact that most tissios aro lisited in their oapacity to do those things nay bo takon as Indeating that this natural funotion is nownally kopt in cheok. Resoarching furthar into control systons for mato activity, Bullough (1959) states that nitotic activito in unounded epicerths is nomally suppressed by sorse inhtbitor producod within the sidn. Fo clans that it is probable that it is tho furction of colls, unloss proTonted, to ropliaste, srou, and divide. Tharaforo, no axtraneous or 
exogenous stimuli noed be required, and substances for Inhibition not stimulation may be the essential factors in anj difforentiating tisoue. Therefore, a stimulue to repatr or regneration may in ract be a lack of Inhibition. Also a stimulus to orergrowth way be frow the action of a hormone whioh oould temporarliy apprese the spectete inhibitor. Cheudhry. Halberg. and Blttner (1956) found inhibition of nitosts by epinephrine in pdnnal epidermis of atoe, conflrating the related atudies by Bullough. Starne (1950) contradicting some of the ofted works, coneludes that a deflatency in the asoretion of the growth hormone of the pltuttary gland rosults in a decrease in the growth of all tiscues soft and skolotal.

Bronotedn, Gray, and Parrott (1952) using an sold seotone extrect of huann plasma, has shown it to be active in partially anintaining the wolght and histologionl strusture of the adronals of hypophyseotondsed rate and clate that ACTH way be demonstrable in human pleoma.

Chaudhry and Halberg (1961) emphacized the 1mportant rolo of the menualian adronal oortex in the comordinetion of physlologle function along the 24 hour soale and in eddition howed the distinctive offects of gland renoval. Adrenalectony lowers the ampletude of the aninals (hamatore), temparature rhytha, and obliterated 1t: pinnal atotle rhythm.

Ballough and Laurence (1961) reported that the suppresation of eptdermal mitotio activity during starvation is due primarily to the inoreasing oonoentration of a mitotio inhibitor. They arggest that this inhibitor is adrenalin seoreted in excoss during the atress of stervation. They state that adronalootomy is followed by a considorable rise in the opidermal 
atotio rate and by the elimination of the diurnal mitotio rhythm. They further augest thet this rhytha is norwally besed on the hour-by-hour variations in the rate of adronalin cooretion. The arake mouse is active. wth a raised adronalin lovel giving a low altotio rate. Conversely, the aleoping mouse is Inactive wth low adronalin lovel giving atgh mitotic rate.

Thetr experiments also showed the effoct of adrenalin in vitro and In rivo by washe out the adrenalin frow the Hasues, with allowed attoses to continue. On flve adrenaloctonlsed miee conslderablo Inoresse oscurred In the opidermal mitotie rate. Adronalin injections on those animal revereed the trond, and lowered the aftotie rete.

ACTH in physiologionl coneentrations does not exert an antimitotio sotion (Eullough, 1955). The same is true of woh mineralocortleolds as desoxyeortieosterone (Bullough, 1952 b). Cortisone, on the other hand, oan poworrully deprose the opideraal aitotio rate in high quantities (Bullough. 1952 b). It 1 eppropriate at this point to note that strose oan occur to experimontal antmals from nolse and/or handling in oages and in tranaforring then to other cages.

To -laborate further on t1 sove Inbibltors, Bullough (1964) atates that under the olroumstanese of wound healing. the optdermal al toses booome insonaitive to adrenalin. He suggests that this ay be due to a fall in the coneentration of the nitosis-inhtbitor of the t1souss, wioh wat be present In order for adrenalin to aot in the way genorully roported. He declares that "all evaliablo ovidence is in agreenent with a theory that nol thar the 
epidermis-specific mitotic inhibitor nor adrenalin is able to function alone, and that in normal epidermis they act together to linit and so to control the epidermal mitotic rate."

Studies on Oral Epithelium

Toto and 0 hha (1962) studied the generation cyole of oral epthelium of the tongue in 36 mice with tritiatad thymidine. They determined ton hours to be the DNA synthesis time and this figure (for DNA synthesis) is corroborated by Joglekar (1964), using the interdental papilia tissue of mice. Toto and Ojha reported the percentage of laboled mitotic figures as follows:

$$
\begin{array}{rr}
1 / 4 \text { hour - } 0 ; & 9 \text { hour }-8 \% \\
1 / 2 \text { hour - } 11 \% & 10 \text { hour }-28 \% \\
1 \text { hour - 39\% } & 12 \text { hour }-15 \% \\
2 \text { hour - } 44 \% & 15 \text { hour }-0 \% \\
4 \text { hour - } 56 \% & 24 \text { hour }-0 \% \\
6 \text { hour - } 66 \% & 48 \text { hour }-0 \%
\end{array}
$$

Dhavan and Toto (1965), using tongua, and palate opitholium of mice, also reported the highest labeled percentago on the palate at ten hours. This value wes given as $95 \%$ of the cells labelod. The ton hour figure was also highest for the dorsum of the tongue ( $94.5 \%$ ) and the ventral surface of the tongue (98\%)

Joglekar (1964), using tritiated thymidine reportad on the oral epitholium (interdental papilla), of normal mice. Sho showed a labelod cell 


\section{2}

doubling time for DNA sythoal ocours from one half hour to ten hours. Th1s oonfirms the recults reported by Toto and Ojha (1962), and by Dhaven and Toto (1965). Joglekar showed that more labelling oocurred in the besel coll layer than in the prickle oell layor during the flret 18 hours after Injection of the 1sotope. Th1s does not conour with the flindings of Krajownkd, Garglulo, and Staffelino (1964), who roportad on hunan fomalo oral epitholium. Their findings show 784 of the colle of attosis in the deop priokle layer and only 226 in the basal layor. Joglokar showed that after 22 hours the grester number of laboled cells oocurred in the priokle oell Iayor, bat this wae due to oell migration.

\section{Hormonal Influenees on oxel Dot the 11ue}

Shkler (1963) reported decreesed dencity of the porlodontal mombrane, decreased onteoblastic sativity, and atrophy of ginglval opltholium coourring aftor bilateral adrenalootony of albano rats. Labello and Sohaffor (1966) reporting on the effects of $2.5 \mathrm{mg}$ oorticono aostate dally and Induced looal feotore (wire 14 gature irritation), confirm that the apparanoe of the porlodontivm was thet of deoreased cellular activity axhlbited by a deoreseo In nubor and ise of fibroblants and osteoblaste. Whon cortisone is adulnlatered in the prowenoe of Irritanta, the reoponse to that irritant is loseened.

Beohnik (1966) studied the effocts of orareatomy upon the synthesis of DHA, and the wigration patterns of oral eplthellal cells of the moues intordental papilia. He found, by means of laboling with tritlated thyuldine. 
that ovariectorny delayed DNA synthesis and thar cby delayed the doubling time of labeled epithelial cells.

Histology of the Mouse Molar Interdental Papilla

Greulich (1961) using thymidine autoradiograms rovealed that DiA synthotic activity and presumably, therofore, nitotic activity in the region of the gingival margin and attached epithelial cuff is considerably greater then that of the adjacent oral mucosal opithelium. These findings support the concept that the tissues of the gingival margin and attached epithelial cuff are modified to perform supportive and protective functions specifically associated with the tooth and should be considered to bo functionally separate from the oral epithelium as a whole. In 1962 Greulich further states that since no evidence of keratinization has been noted and since a continuous cell migration occurs, a firm attachrient to the enamel soems unlikely. On the other hand, it is stated in Orban's Periodontics (from Stern, 1963) "the cells of the epithelial attachment appear to attach to the tooth by a syrstan of homidesmosomes. The systam rescmbles the modo of attaciment of the basal colls to the basement mambrane." Toto (1964) states that the nature of the epithelial relationship to tooth is one of close adhorence maintainod by a nucopolinysaccharide cament.

\section{Autoradiography}

Gross, Bogoroch, Nadlor, and Leblond (1951) showed autoradiography to be a mothod for labeling, tracing and detecting radioisotopes based on their ability to affect the silver bromide crystals of photographic anulsion. 
Firket and Vesley (1956) showed thymidine to be a specific precursor of DNA.

Leblond, Messier, and Kaprirva (1959) showed that if tritiated thymldine is administered during DNA synthesis, the nuclei of these cells will be labeled before mitosis takes place. The labeled DNA is sharod equally by the nuclei of the daughter cells. Messier and Leblond (1960) roported that in ronewing cell populations, largo numbors of labeled nuclei appear after administration of thymidine-H $H^{3}$. Their number then rapidly decreases and disappears as the cells redivide and are finally lost. Hughes, ot al 1958 reported from their work that the time interval that tritiated thymidine is available for cell uptake is one hour. Moreover, after one hour, $95 \%$ of the label is either utilized in DNA replication or excreted. Skougaard (1964) states that the mode of administration is an important factor in detarmining tha cell renewal time. Ho claims that an increaso occurs in the mean grain count corresponding to the time the tracer was available in the blood plasma. Intravenous injoction gave a fast uptake while the intraperitoneal and intramuscular routes of administration wore considerably lower. 


\section{MTIZIAIS AWD METRODS}

Trenty-five Ceeserean Derived $1^{1}$ adronaloctcalized wht of and twenty-r1ve C.D. Tl hpophosectontsed wite mice 45-50 deys of age wth average weight of 30 grans were utilized for these etudies. Euch antinal roooived tritiated thymidino vis intraporitoneal injoction. The spoctelo activity of the 1sotope 1.9 curles per milltrole, and the dose rate was one miarocurle par gram of body waight throe days following the adrenal octouy or hrpophysectany. The injoctions were oarried out within a one hour tho span in order to mintorize tho effeats of tho diumal rothen of nitosis. The first aninals for each study wore sacriflced one hals hour after the Infoctions and tharoafter at the following tine intarrals; $1,2,4,6,8$, $10,12,14,16,18,22,24,28,32,36,40,44,48$ hours; throe, four, and fre days.

The mandibles and soft tissue coverings ware disected out and rixed in a ton poroent formalin solution for one wook. The formalin bath was changed after three days. Following flxation the specinens were deninaralised in a solution of sodiun eftrate and formlo acid as follows:

$$
\begin{aligned}
& \text { Solution A - } 50 \text { grams of sodium oltrate and } \\
& 250 \mathrm{ml} \text { of distilled ter. } \\
& \text { Solution B - } 125 \text { of } 90 \% \text { formic actd and } \\
& 125 \mathrm{ml} \text { of dist1lled water. }
\end{aligned}
$$

Solutions $A$ and $B$ wore mixed in equal parts.

1Tho Charles River House Farms. Inc., Horth Wlintington, Massachusetts. 


\section{6}

Specians were treated in this solution until dosineralization was complete as deterained radiographically. The deminoralisation solution was changed overy day for three days. Specimens wore thon dehydrated in alcohol solutions in sequence from 756 to $95 \%$ and finally to absolute aloohol. The t1ssues were then ebedded in paraffin (T1ssue Mat-FIsher Company). This we carried out in a vaouo at a temperature of $56.5^{\circ} \mathrm{C}$ at 15 pounde por square Inoh for 15 minutes.

Sectioning was porformed on a rotary miorotome at a thieleness of afx sorone. These wore out on a mosiodiatel axis through the wolar area and each afxth section was utillsed for autoradlographe. The sections ware then mounted and deparefrinised by imereton for ton minutes in oach of three ohanges of Xylol, followed by three desoending conoentrations of alcohol. five minutes in absolute aloohol, and three winutes sach in $95 \%$ and $75 \%$ alsohol. Minally the seotions wore washed in distilled water for five uinutes.

Onder darkroom conditions, the slides wore dipped into Ilquid photom Eraphic emuletion (Nuolear Traok Dauldon Type KTBj-Eectman Kodak Coapany) for three seconds, almaried for ten minutes and pleced Into a black. IlghttIght exposure box, seotion alde up. Lithiun Chloride we plooed into the box to maintain low humidity, and black wakdng tape was uoed to light-weal the box. The slides were allowed to expose the enuladon for a period of two weoks at $4^{\circ} \mathrm{C}$. During this time the box wa positioned to keep the ceotione upright. 
Dereloping

The eltdes wore placed in a rack and developed for five alnutos at $60^{\circ} \mathrm{F}$ ( $18^{\circ} \mathrm{C}$ kodak $D 196$ developer). The slldes were then washed in diet1lled water for thirty soconde and placed into acid Nxer reducing solut1on for ten winutes. The slldes were washed in ranning tep rater for 30 winutes and allowed to dry in a strean of alr. When the sldes wore dry. they were dipped into water for 30 seconds and the excess enviolon was trimed from the slides. The seotlons were stained wh th a nuolear fast red, Indigo ourmine sequence. 1 Also, a representative section from each time porlod was stalned wt hematoxylin and cosin without an eutoradlograph belng made. For each time perlod, adx slides were propared by autoradiographic toohnique wth oach slide containing three to Ax sections. The sections were meslodistal through the interdental paptilae of the molar area.

The counts wore performed on the papllile between the first and sooond nolar. At least one section on exoh slide propared was examined and rocorded, alding a minimu of six labeled cell sounte per time interval.

The henatorglin and eosin slides were used in a random sampling to find the average total oplthellal cell popalation par papille. The opitheltal cell population por papilla was determined. The doternination of the laboled cell popalations wa next carried out. Each of the slides for every sacrifloe porlod was examined in both the adrenaloctomised wieo

14cheline Mortreull-Langlote, Department of Couparative Anatomy and Hictologs. Faculty of Solence, Univ. of Paris. Rue Viotor Cousin, Paris. France. 
sories and the hypophyesotonised atce sories. For nore detalled looelisetion of the labeled celle, the papiliee were arbitramly divided into three sones using the thickness (depth) of the eplthelliw as a neasure. Zone I began at the aptoal and of the attaohed ept thellom, and continued coronally until the eplthellum we threo oells ade (deop). Zone II began at this point and continued coronally to a point corrosponding to the ond of the conneative theme (Ianine propria). Zone III consisted of all opt thelfum coronal to the conneotire tiesue (See Flgare 1). Generally, Zone II varied from four to dx cell, deop and Zone III alx and more celle deop. Zone III torminates at the tip of the papilla.

To further olarify the looation of the labeled cells wo recorded their oocurrence in one of three layors of opttholluas the basal lajor celle are on the basement nembrane, the priokle layer oelle above the beal layor. and wresee colls on the surface roady for dosquantion.

A statiotioal analrate of the ocevrrenoe of labeled oolls in the adrenaloctoulsed mouse and the hypophyecetondsed wouse we propared and compared to the reaulte obtelned for the norwal mouse (Joglokar, 1964) and for the ovareotomised mouse (Bachnik, 1966). 


\section{FTwDrwos}

The Interdental papdile of the moras is bationlly terengular in

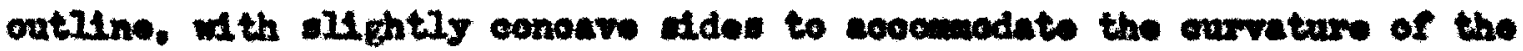
onanel murfwoe of the wolur tooth with wioh it is in elose contect.

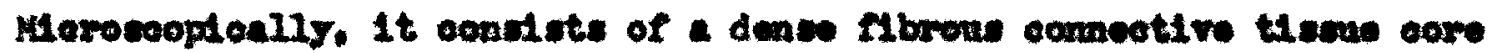

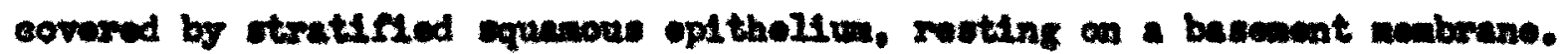
Thowe 1s a beal Iayew. and prioklo oell layor but no pranulameell layor or stretan cornitu in the aloue opithellum. The surfuos layor contains

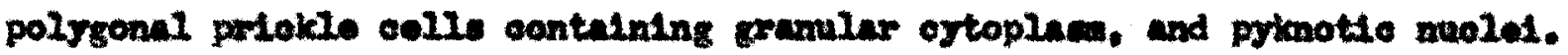

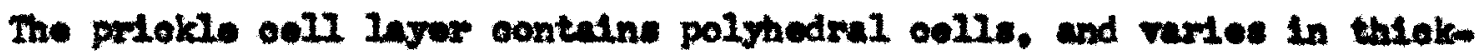
neas. Inorauting frow the and of the opithellal attachment to the tip of the Interdontal papdine.

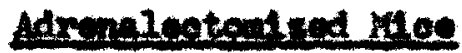

The average opthollal oull popalation for each seotion of the intorw

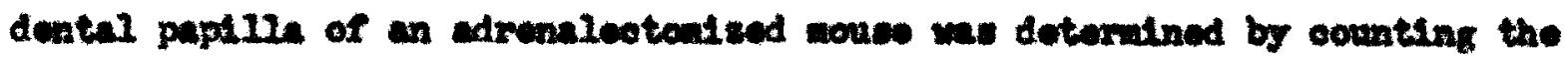
opt thelial aelle of $\mathbf{X}$ papliles. The oell populattone ranged from a lor of 103 oelle to 1 high of 313 oelle. The man opt thellal ooll popalation

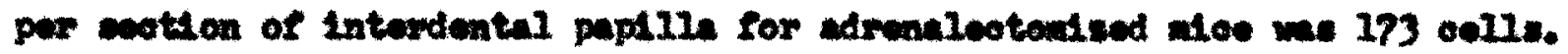

At one hale how 12.5 labeled ealls $(7.26)$ wre som and at one hour thi: vilue foll to $9.0(5.2 \%)$. Then thore was a gradual $\mathrm{H}$ es in the Iabeled oell popriation to 10 oelle. The doubling the of the intial Iabelad cell popalation cocturred at 14 houre. (Tubles $A$ and $B$ ). 
Basal cell layer: The groutest number of laboled oells ocourred in the besal leyor for the firet 24 houre (Table A). The avorage labeled population for one half hour was 8.9 cells. At one hour there wore 5.7 laboled oells, and thoreafter this ralue inoreased to a poak of ofght oells at the 24 hour period. Thereafter. the number of laboled celle por sootion dropped sharply to 4.6 oells at the 44 how porlod, 1.8 oelle for the three day portod, 2.1 oells for the four dey porsod and 0.6 colls for the f1re day portod.

Priekle oell laper: The labeled cell count of the priokle cell laypr began wth an arerage of two oelle at the one half hour porlod for all sones. The cell count gredually inoreased through the early cacrifice hours to reach a peak of 21.3 cells at 20 hours. The number deoreased atead11y to 9.3 at 44 houra, theranter to 5.5 oelle at the three day Interval. 5.1 cell. for the four dey porfod, and 4.6 oells at five days.

surface cell layor, At ons half hour the surface layor showed an average of 1.8 labeled colle. The flgure stondly Inoraced to 8.5 celle et the 44 hour porled. Later porlods shomed a decline in the number of curface lebeled cells ending wth a count of 5.6 at the rive day partod.

Zone distributions In the early hours, the count of the labeled coll population wis conocatrated in Zono I. begiming with 6.5 oells at the one half hour perlod. Zone II showed five colls, and Zone III chowed one oell for the one half hour porlod. Subsequently, the sonos shownd Inoresees up to poak pointe followed by declining counts as follows: zone I rosehed a park of nine laboled oella at 20 hours and deolined to 0.8 at firo days. 
Zone II reached a peak of 21.1 labeled oells at 40 hours, and deolined to 4.6 oells at five daye, Zone III peaked at four days with an average count of 7.3 laboled oello onding at 5.2 oolls for five days (Table B).

Peroentage of labeled oells: The percentage of labeled cells at one half hour was $7.2 \%$. The labeled oell numbers gradually rose to maximum of $19.4 \%$ at 20 hours and then gradually declined through the remaining time poriode, ending with 6.16 at f1re days.

The percentage of labeled cells doubled from $5.2 \%$ at one half hour to 10.54 at 18 hours. The curve of the logerlthin values of the percentages (FIgure 2) of labeled cella whow atralght line to the 26 hour perlod. The rate of increase dininlshed ellghtly from 30 hours to 40 hours, and then declined gradualiy to the IIro day parlod (Table $\mathrm{E}$ ).

\section{Hrpophreectomed Xisee}

The average oell popalation for hypophyeectonleed wloe mas detaralned by cell counts on sectione of 15 interdental papiliae. The Arures determined for these sections ranged frow a low of 123 oelle por papille section to a high count of 250 colls. The mean wa 190 optthellal cells per soction of papilia.

At one hale hour, the sections showed a labeled cell population of 9 cells. Thi me followed by gredual if in in the labeled oell frequenoy to 18. This cocurred at 16 hours.

Bacal cell layor: The basel layor contained the groptest number of labeled cells in the carly hours, and continued so up to 16 hours. At one half hour the average oount we 6.6 labeled oelle par papt 11 . The averege 
Inereased to nine cells at the 16 hour period. This was matntatnod up to 20 hours. The counts then doolined to elght labeled cells at 24 hours, six at 48 hours, three at three days, 2.3 at four days, and finally two labelod cells at the five day sacrifice pertod.

Prlokle coll layer: The prickle cell layer showed an average number of labeled cell: of less than one cell at one half hour. This value increased to 14.3 at 28 hours. The Increases continued Iess sharply to the 44 hour perlod wiloh ahowed an everage value of 16.5 labeled cells. Then the value declined to 8.6 at three days, seven at four days, and ended at five days wth an everage count of 4.5 labeled oolls per seotion. Surface cell layer: At one half hour the surface layor contained an average of 1.6 labeled cells. The number of these sells inoreesed to 13 at the 44 hour perlod. Thereafter, the number diafiniahed raptdly. chording a 5.5 labeled cells at 48 hours: 7.6 labeled oolls more present at three days, and 4.5 at four days, and 5.6 labeled cells at flve days.

Zone distribution: Zone I contatned the great majority of labeled oells begluning with the one half hour perlod. At this polnt the arerage labeled oell population for Zone I was alght, Zone II was 1.3, and Zone III was soro. Each zono gradually inoreased to a peak and thon deolined.

Zone I had the higheat average oount at 16 hours with a figure of 9.5 labeled oelle. The deoltine mas abrapt to $1 x$ lebeled sells at 18 hours, and held newr this figure to 48 howre. The decline was then to 3.3 oel1s at three days; 1.5 at four days and one at flve days. The Zone II average rose from $1.3 \mathrm{cell}$ s at the one half hour porlod to 19.3 cells at 


\section{3}

44 hours. The three day count was of ght labeled celle; the four day count was 5.6 cells, and the I1ve day count was four labeled oells. The Zone III Iabeled oell population remained loss than one for up to elght bours. It remained low (two, three, or four), up to 40 hours. At the 44 hour point the flgure rose sharply to ton celle labeled. The deoline thoreaftor was more gradual as followe: six labeled oolls at 48 hours, olgbt oells at three days, soven oells at four days, and elght celle at five days.

Poreentuge of labeled cells: The poreentage of laboled cells por ecotion of papdila doubled from $4.8 \%$ at one half hour to $9.5 \%$ at ten hours and $9.7 \%$ at 14 hours. Thts ralue inoreased regularly to $13.2 \%$ at 28 hours. The deoline therearter was gradual, shoulng $9.7 \%$ at 36 bours, 11.66 at 48 hours. 10.3\% at three deys, $7.4 \%$ at four days, and $6.7 \%$ at five daym.

Frow the dete reconded in Table $F$, one notices a distinct simlarity between the labeled oell oounts of the adrenalootomized mice and the hypophyseotontred mioe.

Statistical analyol of the values obtalned in this atudy conel sted of doterminations of the moans, standard doviations, and t-tost probabilities (Table G). 


\section{Drscossrom}

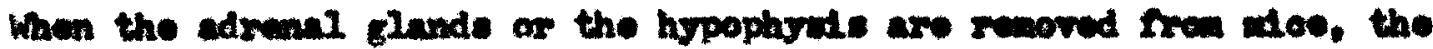

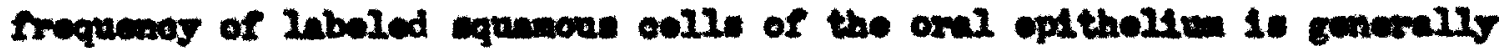

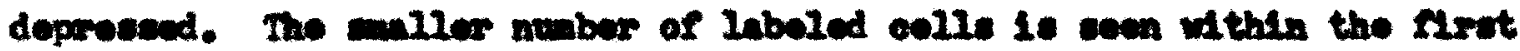

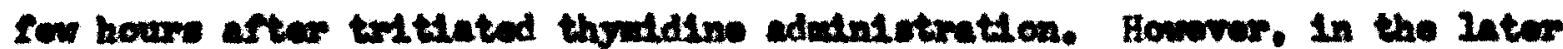
hours of the eill egelo, the Iaboled frequaney rloos above that of the

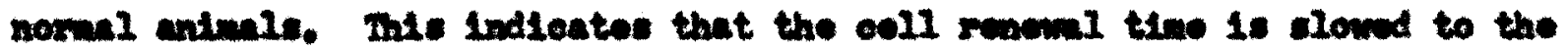

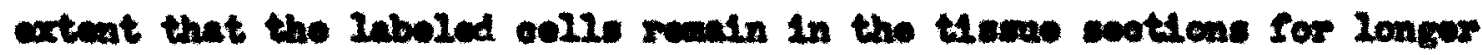
portode of time than the nownel antaels roported by Joglolen (1964).

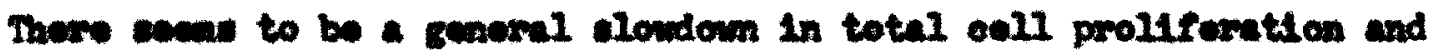

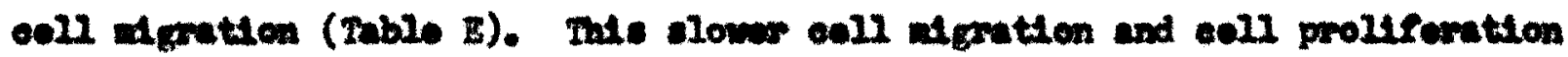
Indlested by the delay in Du doubleng time. 10 probebly doe to the hormonal

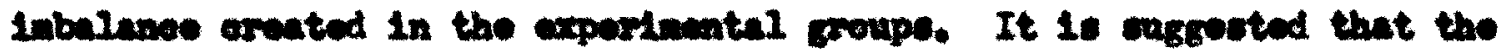

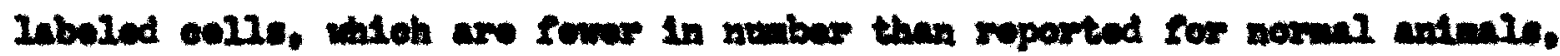

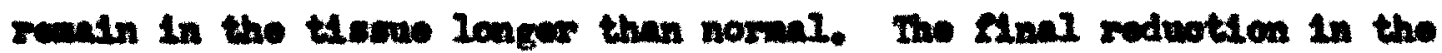

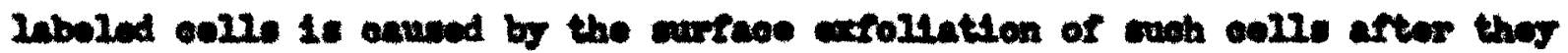

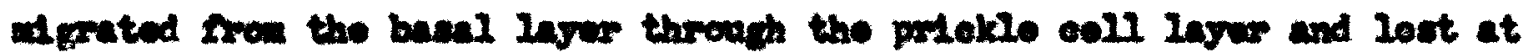
the surewoe.

In the adrmaleotentsed woe the ooll layor distribution (Tablo 1 )

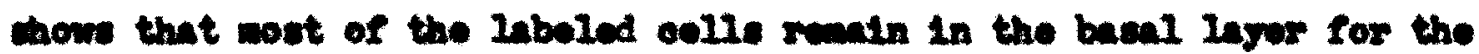
Arot 16 to 22 houre. The parlokle oell layer chownd the croatent muber of Inbeled colle frow 18 hours to the 40 bour the perrlod. Neter that those

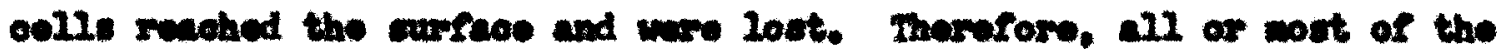

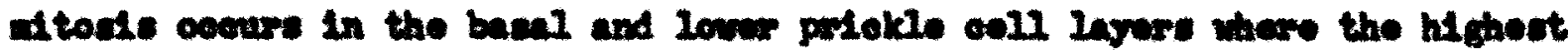




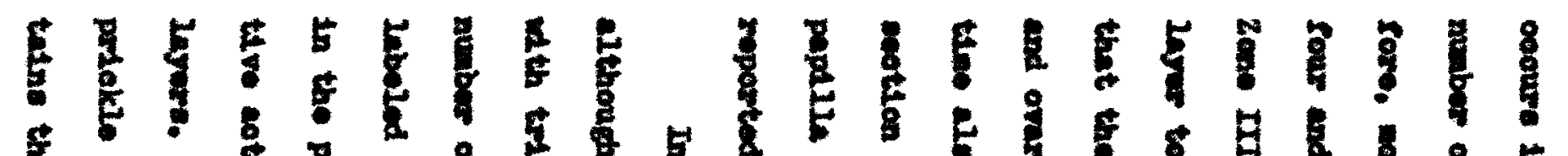

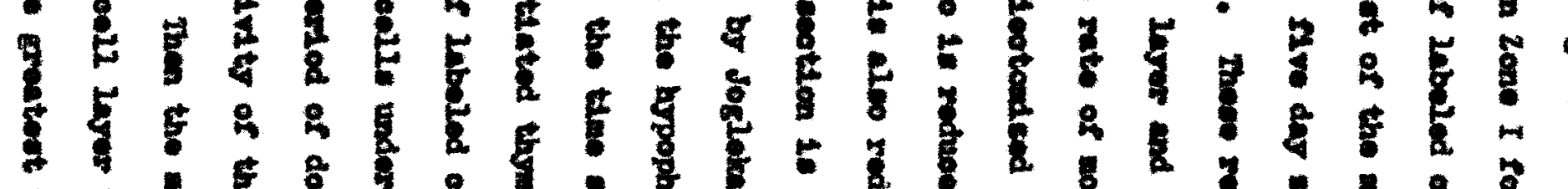
1) 1. क $5=0$ (1)

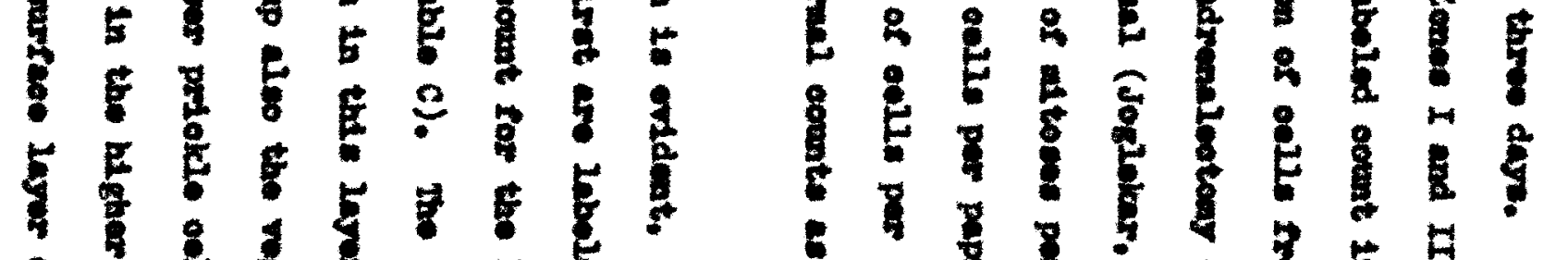
: 
The wigration through the sones follows the pattom of the adrenaleotonized doe (TabIe D). The Zone I oount is the highost from one half hour to 12 hours, and the zone II count 1s higheat from 14 hours to 48 hours. Zone III has the greatest number of labeled oelle in the three, four, and Mre day counts. Agatn, one ceos the same oxderly proceselon of laboled 0.1ls. from layor to layer and from sone to sone, as is observed in the adrenalcotondzed group.

The varlations from normal in the labeled cell counte are the rearlt of the upeet to the dellonte endoomine belanoe, aneed by hormone depulvation rowlting frow the removal of these glands. Ihis same pattern of disturbanoe

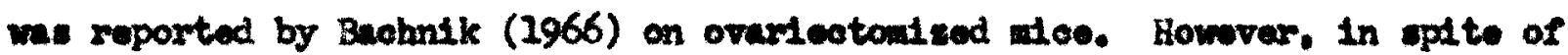
the upset to the andonine balance asused by these gland removals, one is etruak by the faot that the bade runetions of the oolls exanined in this atudy oontinued to oporate, no mattor the altored rete. As stated by Ballough (1959). "1t is the funotion of oelle unloss provented, to roplicate their component molecules, to grow, and to divide."

The magnitude of the fluotuations from the normal compared to our groups and the ovaripotondsed group is worthy of noto. Thore is aeen in the graph (FIgure 2) the logarltha of the poroant of labeled oell counts. The stralght 2 ine feature of the sarly hours of the study indicatos that in the exporinental animals, exouth - as ropresonted by cell proliferation 1. a goometrlo expresaton albelt at a elowar pace than reported for normal antwale (Joglokar, 1964). These ourves are very oloce, Indeed they oross at one point and then continue togethar throughout the experinental period. 
Thore 1s, cocording to the t-teat of probability, vory little chance that these values are acoldently almilar $(p) .001$ ). The difference in the values for the timos of doubling of the labeled coll populations are also different. It is interesting to note the eloseness of these ralues to those obtained by Bechnik (1966) for doubling time of Initial labelod cell population, cell layor distribution, and zono diatribution, and compare all these data to the nomal values roported by Jogleken (1964). Although the ebsolute values reported for the ovarlectoonised group (Bachnik, 1966) are difforent from ours, the pattern of the changer and the soquence of the shifts in labeled cell populations are vory similar. Therefore, considering all together - adrenaleotony, bypophysectomy, and ovar-1ectony (Pachntk, 1966), and oomparing these data to the results of the normal midoe (Joglekax, 1964) - one sees that the nature of the ondocrine syatem disturbance oreated 18 not any more lmportant than the fact 1taolf that a disturbance exists. when the DNA doubling time of oral epithellel colls is ueod as a measure of such disturbence. Nevertholess, suoh disturbanoes produce signifioant depressions in the oell renewal cycle.

These date, however, do not agree with those of Bullough and Laurence (1961), and Chaudhry and Helberg (1961). In thoir oxperiments, on pinnal opidernis of mice using starvation as a stress factor, inoroased mitotic Inhibitor (presumably adrenalin) is seoroted. They also showod adronaloctony to produce a conelderable Inorease in the eppdermal mitotie rate and destruetion of the diumel adtotie rhythm of epideruis. 
Their in-vitro studies also showed adrenalin to inhibit the mitosis. and followed if the washing out of the adrenelln, whereupon the mitosis resumes. It wust also be remembered that in 1959 Ballough and Laurenoe propounded the theory of t1sme-produced Inhibitors (named Chalones in 1964) which are necessery to act in confunction with adrenalin to produce the altotic inhibition. In 1952. Bullough showed that stress produced by orercromding oaused opiderunl attotio rates in aloe to fall $60 \%$. He coneluded that this result was due to inoreased adrenal ontput due to adrenal hypertrophy. At this time the explanation for this apparent contradiotion betwoon our results for adrenalsetomy and those of bullough and Laurence (1961). and Chaudhry and Halberg (1961) eroapes us.

There are algnificant difforences in the means of labeled cells between 28 hours and 44 hours in adrenaleotonized and hypophysectomized animals which showed a divergence trom each other which then nerrowed agein to a very close range of differences after 44 hours $(p<.001)$. The rate of labeling is faster (or slower) in one series versus the other.

The general pattern of labeling frequenoy is docreased from normal as reported by Joglekar (1964) throughout the Firet 24 hours. After this time the percentage of labeled cells in the experimental groups (ovartectomy included) is higher than that reported as norwal (rable E) due primarily to the depressed rate of cell proltferation. The labeled cell count in the experimental group exoeds nomal after 24 hours of the study because the ontire pattern (doubling time and cell migration) of the experimental group 1 slowed.

Therefore, after 24 hourw, a greator percentage of labeled cells has 
beocme lost fros the normel animals, and the laboled popalation 1e et1ll prosent in the section of the experimental group (Table E). This slower movenent and alower doubling time is shown by the inoreased the lapee necesany to comploto the dombling of the intial labeled population. Thorofore, the experinental labeled cell popalation realins indtu longor and boocmos, In effoct, an oldor eell popalation than normal. This delay In coll wovesent explatins the highor numbers of laboled colls coen in the experimental group aftor 24 hours.

If ten hours 1s to be taken as the DNA doubling time for nomal antunis In this type of stody (Toto and OJha, 1962, Dhawan and Toto, 1965: Joglekar. 1964), then our results for adronaleatons at 14 hours, and hypophyecetony at 16 houre as interpreted from the graph (P1gure 2), do Indead reprowent a ohanged (alowed) pattorn. Howovor, our doubling tines as Interpreted from the greph are not apprealably different ron asch other. and that of ovarieotomised wies (Bachnik, 1966) being 14 hours. 


\section{STMuRY}

$A$ hietologloal and oell kinetio study was undertaken on the oral opt thelive of the interdental peptils of adronaleotondsed and of hypophyseotondsed C.D. HI wito wioe 45-50 days of age wolghing approximatoly 30 grans. Iritliated thyuldine (spectifo activity 1.9 cumes por millinolo) wa injected intraporttonealiy at a rato of one morocurle por grea of body wedght. The animels were saomifleed at one half hour, one hour, and tro hours, and rogular two hour intervals up to 24 houra. In addition, asorifloes wore made at four hour intervals up to 48 hours and at the and of three, four, and rive days.

The wandibloe were removed, SIxed and embedded in paraffin by follow Ing the ueval atandard proesduros. Sectlone wre out at a thiclenese of six marone on a mododistal axis through the molar Interdental papilis. Each Arth seotion was need for autoradiography. The sections wore statined it th a nueloar fast rod, Indigo ouraine sequenoe.

Stx apecinens propared in this mannor from each sacriflee animal wore selooted for cxantination. The average number of Iabeled oells compered to non-2aboled oells as well as the loostion of the labeled oelle in the peptile we recorded. The pootition of the labeled cell in the papilia was recorded by dividing the opthellal covering into three sones besed on the thicknese of the epithelim. The average number of laboled oells and the

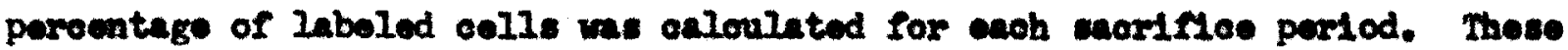
ralnes more compared to those dotornined for the normal wouse (Joglekar. 1964). and those deternined for the ovarleotondaed wouse (Baohntk, 1966). 
31

seratistical analyses for the adronsleotonized and for the hypophyeoctomised ma coensisted of moans, standerd deviations, and t-tent doterninations. 


\section{CONCUUSIONS}

The initial sections at one half hour showed that the first labeled cells appeared in all layers and all sones in both sertos of antwals. The only exception to this pattern 1s the complete lack of labeled cells in Zone III of the hypophyseotondised group. The greatert majority of these labeled oells oocurred in the zone I arees and In the basel lagers of the opt thellum.

After the time lapee of 14 hours in the adrenaleotondsed group and 16 hours in the hypophyeectomized group (the the elepsed for coubling of labeled cell poprlations) the groatent numbers of labeled cells are still present in the basal and prickle coll layers. Thls mone that the celle which undergo nitotio divition in the oral wueose of mioe aro loostod in the basal and lower prioklo cell layors.

The laboled cells mgrated obliquels in a ocronal direction and towards the tooth aurface, where they wore lost into the malous.

The ratos of DNA sythosis and oell mitods aro very admiar in both groups. Both adrenaleotomy and hypophresotomy show these ratos to be about equal as the labeling frequenctes are essantially the ane for both experiwental groups.

The doubling the for labeled oral oplthollun of the interdental paptlia in adronalectomised woe 1s 14 hours, and that doubling time in hypophyseotomised iloe is 16 hours.

These data saggest to as that the inter-relationehtps betwen the adrenal gland and hypophyse (and their horwones) is so olose that the 
33

removal of one gland oreates a disturbanee in the othor gland, and rurtherwore, that the end result patterns are sindiar.

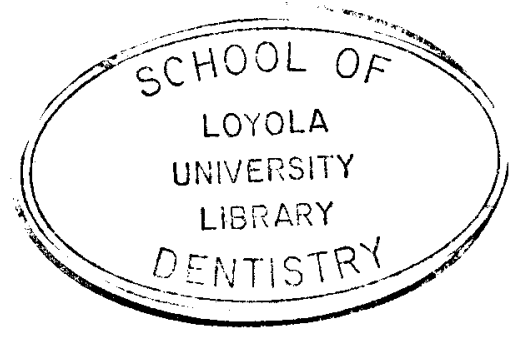




\section{BIBLIOGRAPHY}

Buchnik, Francis L. THE GEUERATION CYCLE OF EPITHEITAL CELLS IN THE MOLAR TITERDENTAL PAPILLAE OF OVARIBCTOMIZED MICE. Thos1s, subuttted for M.S.. Loyola Untversity. 1966.

Best, Charles H. INSULIN, Dlabetes, Vol, 1, No. 4, 1952.

Bornstoln, J.. Gray, C. M., and Farrott. D. M. ADRENOCORTTCOTROPHIC-IIXE ACTIVITY IN PLASWA. J. Endoor.. 8,40, 1952.

Bornetoln, J., Retd, E., and Young, F. R. THE HYPERGLYCAEMIC ACTION OF BLOOD FRON ANIMALS TREATED WTTH GROWTH HORHONE. Nature, 168:903. Hovember, 1951.

Bourne. Geofrrey F. AUTORADTOCRAPHY. Blological Reviews of the Cambridge Ph1 losophtion Sooiety. 27:108. 1952.

Bullough, W. S. AGE AND MITOTIC ACTVITY IN THE MALE MOUSE, KUS MUSCULUS $L_{\text {. }}$ J. Exp. Blol., 26:261, 1949.

Bullough. W. S. THE RELATION BETWEEN THE EPIDERHAL MITOTIC ACTIVITY AND THE BLOOD-SUGAR LEVEL IN THE ADULT MALT MOUSE, MUS YUSCULUS $L . J$. Exp. Blol., 26:83, 1949.

Bullough, $W . S$. THE ENERGY RELATIONS OF MITOTIC ACTIVITY. Hologteal Rovlews of the Canbridge Phtlosophteal Soototy. 27:133. 1952.

Bullough, W. S. STRESS AND EPIDERMAL MITOTIC ACTIVITY: THE ETTBCTS OF THE ADRENAL HOFWONES. J. Endocr.. 8:265, 1952.

Bullough. W. S. A STUDY OF THE HORWONAL RELATIONS OF BPIDERMAL MITOTIC ACTIVITY IN VITRO II INSULIN AND PITUTTARY GROWTH HORMONE. Exp. Coll Res., Vol. 7. 1954.

Bullough, WIIliam S. HORMONES AND MITOTIC ACTIVITY. Vitanins and Hormones, 13:261, 1955 .

Bullough, Whllian S. THE CONTROL OF MITOTIC ACTIVITY IN ADULT MAYMALIAN IISSUES. Blologlonl Revlows of the Canbridge Thilosophlonl Soclety. 37:307. 1962 .

Bullough, WIllan S. GROWTH RBGULATION BY TISSUE-SPBCIFIC FACTORS, OR CHALONES. Cellular Control of Meohantsass and Cancer. 3dited by P. Enrelot and 0 . Muhlbook. Now York: Elsovter Fublishing Co.. 1964. 


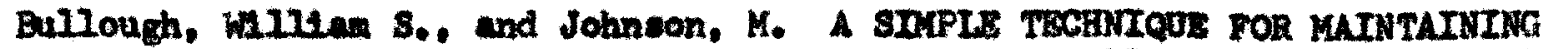
MuRALIAN EPIDRRAL MITOSIS IN VITRO. Bxp. Cell Ros.. Vol. 2, 1951.

Bullough, WhIl1 am S., and Laurenoe, E. B. THE CONTROL OF EPTDERMAL MITOTIC ACTIVITY IN THE MOUSE. Proe. Roy. Soe. Lond. S0r., 151:517. 1959.

Bullough, WILlian S., and Lauronee, B. B. MITOTIC CONTROL BY INTERWAL SECRETIOA: THE ROLS OF THI CRALONE-ADRENALTN COMPLER. BXo. Cell Ros.. 33:176, 1964.

Chaudhry, A. P., Halborg, P., Bttnor, J. J. EPIREPHRINE AND MTTOTIC ACTIVITY IN PINAL EPIDKRIS OF THE HOUSE. J. Appl. Phymol.. 9:265. 1956.

Chaudhry, A. P.. and galbarg. F. ADREAALECTOMY EFTECT ON TBMPERATURE AND EPIDKRAAL KITOTIC RRTHAMS IN HAMSTRRs. J. Dent. Res. (Abstreot). Vo1. 40, No, 4, July-duguat, 1961.

Cohm, B. STUDIBS OF THE INTERDENTAL EPITHELIAL IHTEGUNENT. PROCERDINGS OF THE SEVENTH ANWUAL MEETIWG OF THE I.A.D.R.. ApA11, 1959. J. Dent. Rea.. $38,1219$.

Cort. ADDRESS TO FIRST INTERAMTONAL COWGRESS OF BTOCHBISTRY. CAted by W. S. Bullough, 1955.

Cotas, P. M., Ratd, E., and Young, F. R, DIABETOGENIC ACTION OF PURE ANTBRIOR PITUITARY GROWTH BORLONE. Natuwe, 164:209, Auguet, 1949.

Flrket, H., and Vealv, $W_{*}$ G. AUTORADTOGRAPHIC VISUALIZATIOH OF DNA IH TISSUE CULTURE WITH TRITIU LABELED mMMDINE. Naturo, 181:274, 1957.

Greulloh, g. C. CELL PROLIFERATIOA AWD MIGRATION IN THE EPITHELIAL ATTACHMENT COLHA OF THE MOUSE MOLAR. I.A.D.R., Karoh, 2962.

Groultoh, R, C. EPITHELIAL DHA AND FWA SYNTHETTC ACTIVTTIES OF THE GINCTVAL MARGIN. J. Dent. Res. (Abstraot), Vol. 40, Ho. 4, 1961.

Gross, J.. Bogorooh, R., and Vadlex, H. J., and Lablond, C. P. THE THEDRY AND METHODS OF RADIOAOTOGRAPHIC LOCALTZATION OF RADTOELLAIENTS IN TISSUE. Amer. J. Roentgen.. 65,420, 1951.

Henry, J. Ln, Meyer, J., WoLnmann, J. P.. and Sehour, I. PATTER OF MITOTIC ACTIVITY IN ORAL EPITHaLIDI OF RABBITS. A.M.A. Aroh. Path., 54:281, Sopteaber. 1952. 
Hughes, $W_{0} L_{0}$, Bond, V. P.. Buoher, G., Gronidt, E. P.. Palnter, $R_{0} B_{0}$. Queavtior, H.. and Sheman, F. G. CELLJLAR PROLIFERATION IH THE MOUSE AS REVEALED BI AUTORADTOGRAPHY WITH TRITLATED THMIDINE. Proc. Nat. Aoad. So1.. 44:476, 1958.

Joglekar, A. A. CYTOLOGICAL STUDY OF THE MIGRATION OP THE CELLS OF THE INTERDENTAL PAPILIAE IN THE MOUSR. Thests, Submitted for M.S.. Loyola University, 1960.

Krajowski. J. J., Garglulo, A, W., and Staffelino, H. MITOTIC ACTIVITY IN THE ORAL EPITHELIUM OF THE HUMAN FEMALE. Poriodont1cs, $2: 267,1964$.

Krichesky. Boris. PROCEEDINGS OF THE SOCIETY FOR EXPIRIMENTAL BIOLOCY AND MEDICNE, 34:126, 1936.

Labe110, 只, and Schaffor, E. THE EFFECTS OF CORTISOHE AND INDUCED LOCAL FACTORS ON THE PARIODONTIUN OF THE ALBINO RAT, J. Poriodont. Vol. 37. No. 6. Noveraber-Decenber. 1966.

Loblond, C. P., Mosster, B., and kepriwa, B. THMIDINE-H ${ }^{3}$ AS A TOOL FOR INVESTIGATION OF THE RENEWAL OF CELL POPULATIONS. IAb. Invest.. 8:296. 1959.

Lettre, Hans. SOME INVESTIGATIONS ON CELL BEHAVIOR UNDER VARIOUS CONDITIONS: A REVIEW. Canoer Res.. 12,847, December, 1952.

LOVIn, Hamy L. SOME DENTAL ASPECTS OF ENDOCRINE DISEASES, Cral SurR., Cral Ked., and Orel Path., 19:466, 1965.

Markw, H. P., and Young, F. C. THE "PANCREOTROPIC" ACTION OF ANTSRIOR PITUTTARY EXTRACTS. Chemistry and Industry (Abstract), Vol, 58, No. 27. July. 1939.

Ko Hugh, W. D., and Zander, H. A. STUDIES ON THE MIGRATION OF CELLS IN GINGIVAL CUFF EPITHELIUM. J. Dent. Res.. Vol. 43. No. 5, Septembeructober, 1964.

Messior, B., and Loblond, C. P. CELL PROLFFERATION AND MICRATIOH AS REVEALED BY RAOIOAUTOGRAFHY AFTER INJECTION OF THMIDINE-H ${ }^{3}$ INTO MALE RATS AND MICE. Amer. J. Anat., 106:247. May, 1960.

Raben. M. S.. and Westermeyer. V. W. DIFFERENTIATION OF GROWTH HORMONE FROM THE DTTUITARY FACTOR WHICH PRODUCES DIABETES. Proc. SOO. Exper. Blol. Med., 80:83, 1952.

PLchardson, K. C., and Young. F. G. THE "PAHCREOTRORIC" ACTION OF ANTERIOR PITUITARY EXTRACTS. Jour. Phyralol.. 91:352-364. 1937. 
Shklar, Gorald. THE SFYECT OF BILATERAL ADRBNALECTOMT ON THE PERTODONTIOH AND ALVBOLAR BONE OF THE ALBTNO RAT. I,A.D.R., 41:63. Maroh, 1963.

Skongaard. M. IWFLUENCE OF THE ROUTE OF ADAINISTRATION OF $\mathrm{H}^{3}$-TAMTIOINE ON THE DETERNINATION OF CELL RENEAAL IN GINGIVAL BPITHELIUM OF THE MARMOSET. J. D. ReE., 43:762, September-Cotobor, 1964.

Stafne, E. C. DENTAL ROENTGBNGORAFHIC ASPBCTS OF SYSTEMTC DISEASE. J.A.D.A. $40: 265.1950$.

Stern. I. B. ELECTRON MICROSCOHIC OBSERVATIONS OF THE DENTOGINGIVAL ATTACHMENS IN RAT RICISORS. C1ted by Grant, Storn, and Bverott. Crban's Feriodontios. St. Louis: The C. V. Kosby Co., 1963.

Stann, M. M. THE CONIROL OF CELL DIVISION: A FEVIEN. Cancer Res.. 18:1118. November, 1958.

Toto, Patrick D., and Grandel, Eugene R. ACID MUCOPOAYSACCHARIDES IN TAE ORAL EFITHELIUM. PEMIodont108. VoI. 4, No. 3. 1966.

Toto, Patrlok D., and OJha, Gokul. GENBRATION CYCLE OF ORAL EPITHELIOM IN MICE. J. D. ROS., Vol. 41. No. 2, 1962.

Toto, Patrick D., and Sicher, Harry. THE EPITHELTAL ATTACRMENT. Poriodont1os, 2:154, 1964 .

Trott, J. R.. and Gorensteln, S. I. MITOTIC RATES IN THE ORAL AND GINGIVAL EPITEELIOM OE THE RAT. ATch, Oral Biol., 8:425. 1963.

Young, F. G. GROWTH HORMONE AND EXFERIYENTAL DIABETES. J. J. Clin. Endoor.. 11:531, 1964 .

Young. F. G. THE GROWTH HORMONE AND DIABETES RECENT PROGRESS IN RORMONE RESEARCH. J. Clin, Endoor.. 8:471, 1953.

Zander, Helmat A. A METHOD FOR STODYIF "THE EPITHELTAL ATTACHMSNT." J. Dent. Res... 35:308, 1956.

Z1skind, D., and Blaokberg, S, N. THE ETTECT OF CASTrATION AND HTPOPHYSBCTOM ON THE GINGIVAL AND ORAL MUCOUS MEMBRANES OF RHESUS MONKETS. J. Dent. Res.., 19:381, 1940 . 


\section{TABLE A}

\section{Adranalectandzod Mico}

The Average Distribution of Labeled Colls hecording to Coll Layer at Various

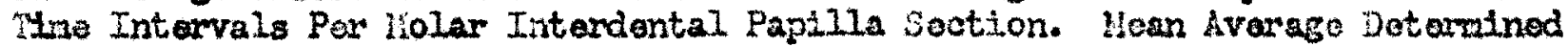
fron Six Soctions in Each Fine Poriod.

Basal

Tine Cell Layer
Priaklo Coll Layor
Avorage

Surfaco

Call Layor
Total

Number
* Avarago * *avorago Totsl Total

Numbar Numbar Nomal Ovarioctory

\begin{tabular}{|c|c|c|c|c|c|c|}
\hline thr & 8.9 & 2.0 & 1.8 & 22.5 & 11 & 4.8 \\
\hline 1 he & 5.7 & 2.3 & 2.0 & 9.0 & 10 & 4.4 \\
\hline $2 h r$ & 4.1 & $3 \cdot 3$ & 2.3 & 9.8 & 15 & 2.8 \\
\hline 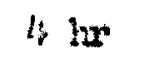 & 4.6 & 6.0 & 2.8 & 13.5 & 19 & 6.2 \\
\hline $6 \mathrm{hr}$ & 5.6 & 3.9 & 3.1 & 12.5 & 26 & 6.2 \\
\hline $8 \mathrm{hr}$ & 0.1 & 0.0 & 0.3 & 0.5 & 17 & 5.2 \\
\hline $10 \mathrm{hr}$ & 6.1 & $5 \cdot 3$ & 4.5 & 16.0 & 27 & 7.8 \\
\hline $12 \mathrm{hr}$ & 7.1 & 5.0 & 2.6 & $1+6$ & 7 & 5.8 \\
\hline $74 \mathrm{br}$ & 3.8 & 6.5 & 4.0 & 14.3 & 25 & 10.6 \\
\hline $16 \mathrm{hr}$ & 5.6 & 10.1 & 3.8 & 18.0 & - & 10.1 \\
\hline $18 \mathrm{hr}$ & 5.8 & 8.1 & 4.3 & 18.3 & 26 & 11.0 \\
\hline $20 \mathrm{hr}$ & 7.0 & 21.3 & 5.5 & 33.6 & 17 & 10.7 \\
\hline $22 \mathrm{nr}$ & 6.0 & 7.5 & 4.8 & 20.1 & 26 & 7.0 \\
\hline $24 \mathrm{kx}$ & 8.0 & 6.6 & 6.6 & 21.2 & 16 & 6.7 \\
\hline $28 \mathrm{hr}$ & 3.0 & 8.8 & 4.8 & 16.6 & $18(26 \mathrm{hx})$ & 6.5 \\
\hline $32 \mathrm{hr}$ & 1.3 & 6.0 & 4.1 & 11.5 & 17 & 6.9 \\
\hline $36 \mathrm{hr}$ & 3.4 & 6.8 & 3.6 & 13.3 & 9 & 6.5 \\
\hline $40 \mathrm{kr}$ & 4.3 & $13 \cdot 3$ & 6.0 & 23.6 & $10(42 \mathrm{hr})$ & 7.8 \\
\hline $44 \mathrm{br}$ & 4.6 & 9.3 & 8.5 & 22.5 & 10 & 6.1 \\
\hline $3 d x y$ & 1.8 & 5.5 & 1.3 & 2.3 & $?$ & 4.2 \\
\hline 4 day & 2.1 & 5.1 & 5.6 & 13.0 & 14 & 2.0 \\
\hline $5 \mathrm{deg}$ & 0.6 & 4.6 & 5.6 & 10.8 & 3 & 2.8 \\
\hline
\end{tabular}

* Joglekar (1964)

* 3achnik (1966) - 1 papilia

*** $8 \mathrm{hr}$ - poor slldos, unreliablo rading 
THOLE

Adronalectorised iseo

Average Dutribution of Laboled Colls According to Zonos at Varions pure In

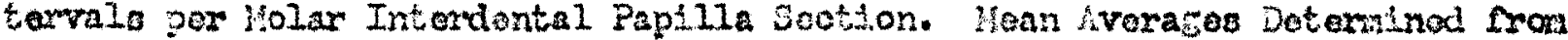
Stx Seotions in Each ing Pariod.

\begin{tabular}{|c|c|c|c|c|c|c|}
\hline $74 n$ & Zone & $\begin{array}{l}\text { Zono } \\
\text { II }\end{array}$ & $\begin{array}{l}\text { Zone } \\
\text { III }\end{array}$ & $\begin{array}{l}\text { Averago } \\
\text { TotaI } \\
\text { I. II. III }\end{array}$ & $\begin{array}{l}\text { Zonos } \\
\text { I, IT, II } \\
\text { Avorago } \\
\text { Total Womal }\end{array}$ & $\begin{array}{l}\text { Zones I, II, III } \\
\text { Avorego } \\
\text { * Total Crarbotory }\end{array}$ \\
\hline 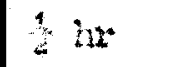 & 6.5 & 5.0 & 1.0 & 12.5 & 11 & 4.8 \\
\hline $1 \mathrm{hr}$ & 4.3 & 4.0 & 0.7 & 9.0 & 1.0 & 4.4 \\
\hline $2 \mathrm{hr}$ & 5.1 & 3.0 & 2.3 & 9.3 & 15 & 2.8 \\
\hline $4 h$ & 4.6 & 4.5 & 4.3 & 13.5 & 12 & 6.2 \\
\hline $6 \mathrm{ht}$ & 6.5 & 5.0 & 0.5 & 12.5 & 16 & 6.2 \\
\hline $6 \mathrm{hx} * * *$ & 0 & 0.1 & 0.3 & 0.5 & 17 & 5.2 \\
\hline $10 \mathrm{hr}$ & 7.5 & 3.0 & 2.1 & 16.0 & 27 & 7.8 \\
\hline $12 \mathrm{ks}$ & 5.2 & 3.5 & 1.1 & 14.6 & 7 & 5.0 \\
\hline $24 \mathrm{hr}$ & 3.8 & 2.5 & 1.0 & 14.3 & 25 & 10.6 \\
\hline $16 \mathrm{hr}$ & 3.8 & 30.5 & 2.0 & 18.0 & - & 20.1 \\
\hline $18 \mathrm{br}$ & 6.1 & 10.1 & 2.0 & 18.3 & 26 & 11.0 \\
\hline $203 x$ & 9.0 & 23.1 & 5.1 & 33.6 & 37 & 10.7 \\
\hline $22 \mathrm{kn}$ & 8.3 & 10.5 & 1.3 & 20.1 & 26 & 7.0 \\
\hline $24 \mathrm{hr}$ & 3.0 & 11.8 & 1.0 & 21.2 & 16 & 6.7 \\
\hline $20 \mathrm{hr}$ & 4.1 & 10.6 & 2.0 & 16.6 & $20(26 \mathrm{~km})$ & 6.5 \\
\hline $32 \mathrm{ln}$ & 4.1 & 6.3 & 1.0 & 11.5 & 27 & 6.9 \\
\hline $36 x$ & 4.4 & 33.6 & 4.8 & 13.3 & 9 & 6.5 \\
\hline $10 \mathrm{~s}$ & 5.0 & $13 \cdot 5$ & 5.1 & 23.6 & $10(42, m)$ & 7.8 \\
\hline $4+2 x$ & $8 \cdot 3$ & 0.5 & 5.6 & 22.5 & 10 & 6.1 \\
\hline $3 \mathrm{davs}$ & 1.5 & 6.5 & 1.0 & $9 \cdot 3$ & 7 & 4.2 \\
\hline 4days & 4.6 & 1.0 & $7 \cdot 3$ & 13.0 & W & 2.0 \\
\hline 5 days & 0.6 & 4.6 & 5.2 & 10.8 & 3 & 2.8 \\
\hline
\end{tabular}

Joglolar (106\%)

3achnl: (1966) - paptila

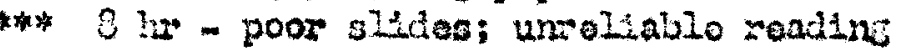




\section{TABLE C}

Iupophrsectonizod ince

Averago Distribution of Laboled Cells According to Coll Layer at Various nue Intervals por Yolar Papilla Dection. Yean Averages Determinad from S1z Soctions In Each Time Pariod.

\begin{tabular}{|c|c|c|c|c|c|c|}
\hline Tsmo & $\begin{array}{l}\text { Basal } \\
\text { Coll } \\
\text { Layor }\end{array}$ & $\begin{array}{l}\text { Pricile } \\
\text { Coll } \\
\text { Layar }\end{array}$ & $\begin{array}{l}\text { Sirfaco } \\
\text { Call } \\
\text { Layar }\end{array}$ & $\begin{array}{l}\text { Averago } \\
\text { Pota1 } \\
\text { Numbor }\end{array}$ & $\begin{array}{l}\text { Norinal } \\
\text { Total No. }\end{array}$ & $\begin{array}{c}\text { Wrartoctory } \\
\text { Total. No. }\end{array}$ \\
\hline $3 x$ & 6.6 & 0.6 & 2.6 & 9.1 & 11.0 & 4.8 \\
\hline $2 \mathrm{hr}$ & 6.1 & 1.5 & 2.1 & 9.0 & 20.0 & 4.4 \\
\hline $2 \mathrm{~mm}$ & 7.0 & 1.6 & 3.1 & 11.6 & 25.0 & 2.8 \\
\hline $4 h x$ & 4.6 & 4.0 & 2.3 & 11.0 & 29.0 & 6.2 \\
\hline $6 \mathrm{hr}$ & 3.5 & 2.1 & 1.5 & 7.1 & 16.0 & 6.2 \\
\hline $8 \mathfrak{h}^{* * * * *}$ & $-\infty$ & $-\infty$ & - س-س & - & - & - \\
\hline $10 \mathrm{hr}$ & 8.3 & 4.6 & 4.0 & 16.0 & 27.0 & 7.0 \\
\hline $12 \mathrm{hr}$ & 4.0 & 4.2 & 4.0 & 12.2 & 7.0 & $5.8 * * * *$ \\
\hline $14 \mathrm{hr}$ & 3.6 & 17.6 & 3.3 & 10.6 & 25.0 & 20.6 \\
\hline $16 \mathrm{hr}$ & 9.0 & 5.5 & 7.0 & 21.3 & $m-m$ & 10.1 \\
\hline $18 \mathrm{hr}$ & $7 \cdot 5$ & 5.1 & 5.5 & 18.0 & 18.0 & 11.0 \\
\hline $20 \mathrm{hr}$ & 9.0 & 7.4 & 3.2 & 19.4 & 27.0 & 10.7 \\
\hline $22 h x$ & 6.3 & 6.1 & 6.0 & 13.5 & 26.0 & 7.0 \\
\hline $24 \mathrm{hr}$ & 8.0 & 9.0 & 6.5 & 23.5 & 16.0 & 6.7 \\
\hline $20 \mathrm{w}$ & 6.0 & 14.3 & 4.5 & 25.0 & $-m$ & 6.5 \\
\hline $32 \mathrm{hr}$ & 4.6 & 6.4 & 8.6 & 19.6 & 27.0 & 6.9 \\
\hline $36 \mathrm{hr}$ & 4.4 & 8.3 & 5.5 & 10.5 & 9.0 & 6.5 \\
\hline $40 \mathrm{hr}$ & 3.0 & 5.3 & 5.3 & 13.5 & 10.0 & 7.8 \\
\hline $44 \mathrm{in}$ & 7.0 & 16.5 & 13.0 & 36.3 & 10.0 & 6.1 \\
\hline $46 \mathrm{hr}$ & 6.0 & 10.8 & 5.5 & 22.0 & 9.0 & 6.4 \\
\hline 3 days & 3.0 & 0.6 & 7.6 & 19.5 & 7.0 & 4.2 \\
\hline 4 days & 2.3 & 7.0 & 4.5 & 14.0 & 14.0 & 2.0 \\
\hline 5 days & 2.0 & $4 \cdot 5$ & 5.6 & 13.0 & 3.0 & 2.0 \\
\hline
\end{tabular}




\section{MEID D}

\section{IVpophysectonized liteo}

verace Distribution of Labolod Colls Acoordint to Zonas at Various Tine In-

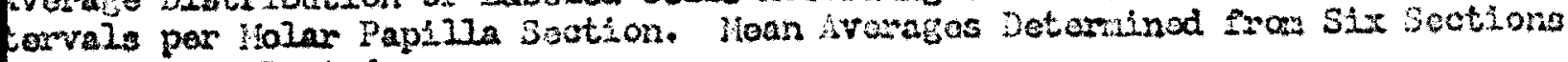
on Eâh Who Period.

\begin{tabular}{|c|c|c|c|c|c|c|}
\hline Pino & $\begin{array}{c}\text { Zono } \\
I\end{array}$ & $\begin{array}{l}\text { Zone } \\
\text { II }\end{array}$ & IIII & $\begin{array}{l}\text { Total Colls } \\
\text { Zonos } \\
\text { I. II. III }\end{array}$ & $\begin{array}{l}\text { *Homal } \\
\text { Avarago } \\
\text { Iotal lumbar }\end{array}$ & $\begin{array}{l}\text { Tartactory } \\
\text { Fotal } \\
\text { Thubar }\end{array}$ \\
\hline$\therefore \mathrm{m}^{n}$ & 0.0 & 1.3 & 0.0 & 9.0 & 11.0 & 4.6 \\
\hline $1 \mathrm{hr}$ & 3.6 & 4.3 & 0.8 & 9.0 & 10.0 & 4.4 \\
\hline $2 \mathrm{~h}$ & 7.0 & 4.3 & 0.3 & 12.6 & 15.0 & 2.8 \\
\hline $4 h$ & 4.0 & 6.3 & 1.0 & 11.0 & 19.0 & 6.2 \\
\hline $6 \mathrm{~m}$ & 2.3 & 4.3 & 0.3 & 7.0 & 16.0 & 6.2 \\
\hline e hr & - & $m-m$ & $-m$ & - & 17.0 & 5.2 \\
\hline $10 \mathrm{wr}$ & 3.0 & 7.6 & 2.0 & 18.0 & 27.0 & 7.0 \\
\hline $12 \mathrm{~m}$ & 5.4 & 5.0 & 1.0 & 12.2 & 7.0 & 5.8 \\
\hline ut ne & 3.6 & 12.0 & 3.0 & 18.6 & 25.0 & 10.6 \\
\hline $15 \mathrm{hr}$ & 3.5 & 10.5 & 1.3 & 21.3 & - & 10.2 \\
\hline $10 \%$ & 6.0 & 9.0 & 2.5 & 18.0 & 26.0 & 11.0 \\
\hline $20 \mathrm{~m}$ & 5.4 & 11.0 & 3.0 & 19.4 & 27.0 & 10.7 \\
\hline $22.3 x$ & 5.6 & 9.0 & 4.0 & 10.5 & 26.0 & 7.0 \\
\hline $24 \mathrm{~lx}$ & 5.6 & 15.0 & 3.0 & 23.5 & 35.0 & 6.7 \\
\hline $20 \mathrm{ir}$ & 5.3 & 15.3 & 4.1 & 25.0 & $18.0(26 \mathrm{x})$ & 6.5 \\
\hline $32 \mathrm{hr}$ & 5.6 & 9.8 & 4.0 & 19.6 & 17.0 & 6.9 \\
\hline $36 \mathrm{hr}$ & 5.0 & 9.3 & 4.0 & 10.5 & 9.0 & 6.3 \\
\hline to hr & 4.0 & 6.6 & 3.0 & 13.5 & $10.0(42 \mathrm{lr})$ & 7.6 \\
\hline $44 \mathrm{n}$ & 6.8 & $19 \cdot 3$ & 10.0 & 36.3 & 10.0 & 6.1 \\
\hline $48 \mathrm{Mr}$ & 6.0 & 10.6 & 6.0 & 22.0 & 9.0 & 6.4 \\
\hline $3 \mathrm{dats}$ & $3 \cdot 3$ & 8.0 & 8.0 & 19.5 & 7.0 & 4.2 \\
\hline 4 days & 1.5 & 5.6 & 7.0 & 34.0 & $1 \% 0$ & 2.0 \\
\hline \multicolumn{7}{|c|}{ 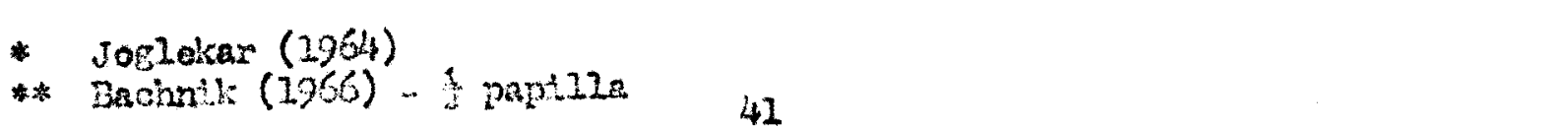 } \\
\hline
\end{tabular}




\section{TABLE: $E$}

Adranaloctonizod liteo and ivpopiysactorized Hice

Porcontage of Laboled Colls an Ppithellum of Intardontal Papilla Sootions at Varlous Thae Intervals.

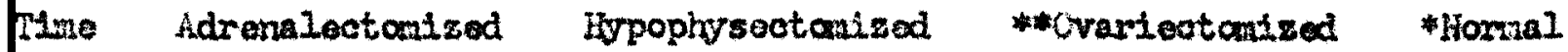

$\frac{1}{2}$ hr

$1 \mathrm{hx}$

$2 \mathrm{hr}$

$4 \mathrm{in}$

$6 \mathrm{hr}$

8 hr

$10 \mathrm{irs}$

$12 \mathrm{br}$

$24 \mathrm{hr}$

$16 \mathrm{hr}$

$28 \mathrm{hr}$

co in

22 hr

$24 \mathrm{hr}$

26.9

28 ar

$32 \mathrm{hs}$

$3 . \mathrm{hr}$

$40 \mathrm{hr}$

$4 \mathrm{hr}$

$10 \mathrm{hr}$

3 days

4 disys

5 dajs
7.23

5.23

$5.6 \%$

7.0

7.23

0.3

$9.2 \%$

$0.5 \%$

8.28

$10.4 \%$

10.5

19. $4 \%$

$11.6 \%$

$12.2 \%$

-m-m

$9.3 \%$

$6.5 \%$

$7.9 \%$

$13.6 \%$

$13.0 \%$

$5.3 \%$

$7.5 \%$

6.13
4.9

$4.7 \%$

$6.3 x^{d}$

5.3

3.7

-.....

3.56

6.45

$9.7 \%$

$11.2 \%$

$9.4 \%$

10.2

9.7

$12.1 \%$

$13.2 \%$

10. $2 \%$

9.7

7.13

19.1

11. $6 \%$

$10.3 \%$

7.4

$6.7 \%$
$5.0 \%$

$4.6 \%$

$2.9 \%$

6.5

$6.5 \%$

5.48

$3.1 \%$

$6.0 \%$

11.08

$20.5 \%$

11. $5 \%$

11.19

7. 3\%

$7.0 \%$

-man-

$6.8 \%$

7.2 ?

$6.8 \%$

2. $2 \%$

6.4

6.7

$4.4 \%$

$2.1 \%$

$2 . \%$
$6.0 \%$

6.08

$2.0 \%$

10.54

$9.0 \%$

$10.0 \%$

$15.0 \%$

$4.0 \%$

14. $5 \%$

-

$15.0 \%$

$10.0 \%$

15.08

$9.0 \%$

10.4

$10.0 \%$

$5.0 \%$

-...-

6.0\%

$5.0 \%$

is. 0 .

$0.0 \%$

1.73

* Joclokar (190ir)

* Baoinnik (1966) - tap papilla 


\section{TABIE $F$}

Adrenaloctontzod Mce and Hpophysoctontaed ifico

Comparison of Avorase Total humber of Labelad Cells per 3action at Vartous ine Intarvals.

Hno Adrenaleotatized Ifpophyseotomizod *ovarioctonjed Homal

thr

$1 \mathrm{hr}$

2 in

$4 \mathrm{in}$

$6 \mathrm{hr}$

$8 \mathrm{hr}$

$10 \mathrm{hr}$

$12 \mathrm{~m}$

$14 \mathrm{hr}$

$16 \mathrm{hr}$

$10 \mathrm{hr}$

$20 \mathrm{hr}$

$22 \mathrm{hr}$

24 kx

$26 \mathrm{kr}$

$28 \mathrm{hr}$

32 kn

$36 \mathrm{hr}$

ito $\mathrm{hr}$

lis: 3

$48 \mathrm{hx}$

3 days

it days

5 days
12.5

9.0

9.8

13.5

12.5

0.5

16.0

14.8

$16 \cdot 3$

18.0

18.3

33.6

20.2

21.2

16.6

11.5

13.8

23.6

22.5

$-$

9.3

13.0

10.8
9.1

9.0

11.6

11.0

7.1

-.w.

18.0

12.2

18.6

21.3

13.0

19.4

18.5

23.5

25.0

19.6

18.5

13.5

36.3

22.0

19.5

$1 \% 0$

13.0
4.8

4.4

2.8

6.2

6.2

5.2

7.8

5.8

10.6

10.1

11.0

10.7

7.0

6.7

$-$

6.5

6.9

6.5

7.8

6.1

6.4

4.2

2.0

2.8
11.0

10.0

15.0

19.0

16.0

17.0

27.0

7.0

25.0

$-m$

18.0

17.0

26.0

16.0

30.0

-m.

17.0

9.0

10.0

10.0

9.0

7.0

24.0

3.0

* Joglokar (1964)

* Bachntk (1965) - I pap1112 


\section{TABLE $G$}

Comparison of Mean, Standard Deviation, and T-Test for Adrenaleotontzod and tupophysectorited itce.

\begin{tabular}{|c|c|c|c|c|c|c|c|}
\hline isto & $\begin{array}{l}\text { Adren } \\
\text { Mean }\end{array}$ & $\begin{array}{l}\text { ated Hoe } \\
\text { Standard } \\
\text { Doviatton }\end{array}$ & $\begin{array}{l}\text { bepop } \\
\text { Mean }\end{array}$ & $\begin{array}{l}\text { alad Hioo } \\
\text { Standaxd } \\
\text { Deviation }\end{array}$ & $T-$ Tost & Probabs & Ity \\
\hline$\frac{1}{2} \mathbf{h r}$ & 12.5 & 3.2 & 9.1 & 2.9 & 4.8 & $p>$ & .001 \\
\hline $1 \mathrm{hr}$ & 9.0 & 3.68 & 9.0 & 4.9 & 0.0 & $p>$ & .001 \\
\hline $2 \mathrm{hr}$ & 9.8 & 3.55 & 11.6 & 5.3 & 2.2 & p) & .001 \\
\hline $4 \mathrm{~b}$ & 13.5 & 3.8 & 11.0 & 4.6 & 3.0 & $p>$ & .001 \\
\hline $6 \mathrm{hw}$ & 12.5 & 6.44 & 7.1 & 2.85 & 7.0 & $0<$ & .001 \\
\hline $10 \mathrm{br}$ & 26.0 & 9.34 & 18.0 & 5.73 & 1.0 & $p>$ & .001 \\
\hline $12 \mathrm{kr}$ & 14.8 & 6.11 & 12.2 & 4.55 & 2.8 & p $>$ & .001 \\
\hline $14 \mathrm{hr}$ & 14.3 & 8.5 & 18.6 & 7.06 & 4.0 & $p>$ & .001 \\
\hline $16 \mathrm{hx}$ & 18.0 & 7.55 & $21 \cdot 3$ & 8.47 & 3.0 & $p>$ & .001 \\
\hline $18 \mathrm{hr}$ & 18.3 & 1.9 & 18.0 & 4.22 & 0.4 & & .001 \\
\hline $20 \mathrm{hr}$ & 33.6 & 13.30 & 19.4 & 9.9 & 10.0 & $p<$ & .001 \\
\hline $22 \mathrm{hr}$ & 20.1 & 2.70 & 18.5 & 5.87 & 2.0 & $p>$ & .001 \\
\hline $24 \mathrm{hr}$ & 21.2 & 2.9 & 23.5 & 7.44 & 2.5 & & .001 \\
\hline 23 ins & 16.6 & 2.13 & 25.0 & 7.28 & 9.8 & $p>$ & .001 \\
\hline $32 \mathrm{br}$ & 11.5 & 2.04 & 19.6 & 3.94 & 21.1 & $p<$ & .002 \\
\hline $36 \mathrm{kr}$ & 13.8 & 4.6 & 18.5 & 4.03 & 18.5 & $p<$ & .001 \\
\hline $40 \mathrm{~m}$ & 23.6 & 5.03 & 13.5 & 7.5 & 10.0 & $p<$ & .001 \\
\hline $44 \mathrm{hz}$ & 22.5 & 20.17 & 36.3 & 0.39 & 10.6 & $\mathbf{p}<$ & .001 \\
\hline 3 days & 9.3 & 2.25 & 19.5 & 8.75 & 4.08 & $\mathbf{P}>$ & .001 \\
\hline 4 days & 13.0 & 1.88 & 14.0 & 4.12 & 1.4 & $p>$ & .001 \\
\hline $5 \mathrm{dag}$ & 10.8 & 1.9 & 13.0 & 5.05 & 2.7 & $\mathbf{p}>$ & .001 \\
\hline
\end{tabular}




\section{TABLE}

Wistologie Fonulas and Proceduros

\section{Dorinaraliestion Solution}

Solution A consiated of fifty grass of sodiun attrate and 250 co of distilled tor. Solution B consloted of 125 oo of 908 formis and and 125 cc of distlilod ter. Solutions $A$ and $B$ were mixad together in equal parts. Specinens wore allowed to rapain in this solution until demenema Ization ias completo sa detemened by roentgenographs.

\section{Imoloar Fast Red, Indiro Caritno Sequence}

Tho sifdes woro placod for ono to five mimtes in a nonaqueous solution of $\%$ aluming sulfate, contalning 0.1 nuclear fast wod (Rernechtrot

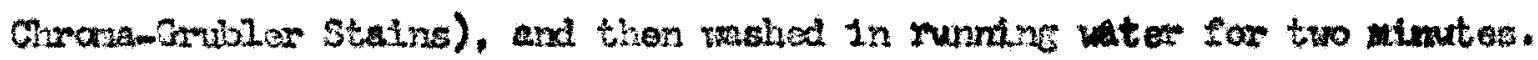
Next they vere imarsod in a saturated zolution of plome acid to whoh $0.25 \%$ of indigo armino had been added for thirty soconds. Than thoy wara quiakly dahydratad by throe changea of ajsolube aloohol, aloared in two changes of xylons, and mountad in Canda balsan. 
Figure 1. Illustration of the three sones of ept thelium in Intordental papille of the mouse enlooted for counting conventence. 


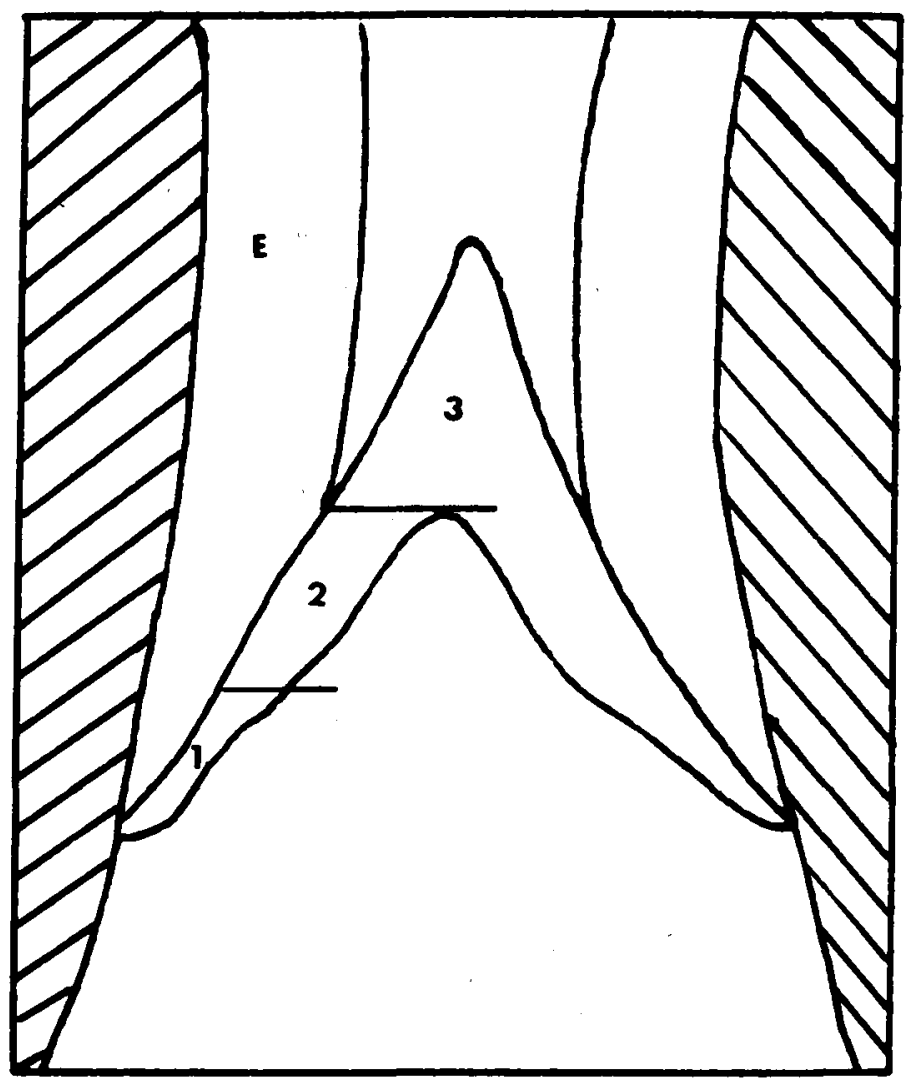


Figure 2. A graph representing the logarithm of the percent values of labeled cells in the oral eptheltum of interdental pepilla of adrenalectorized and of hypophysectomized mioe. The perpendicular lines represent the time elapsed for the doubling of each initial labeled cell population. 


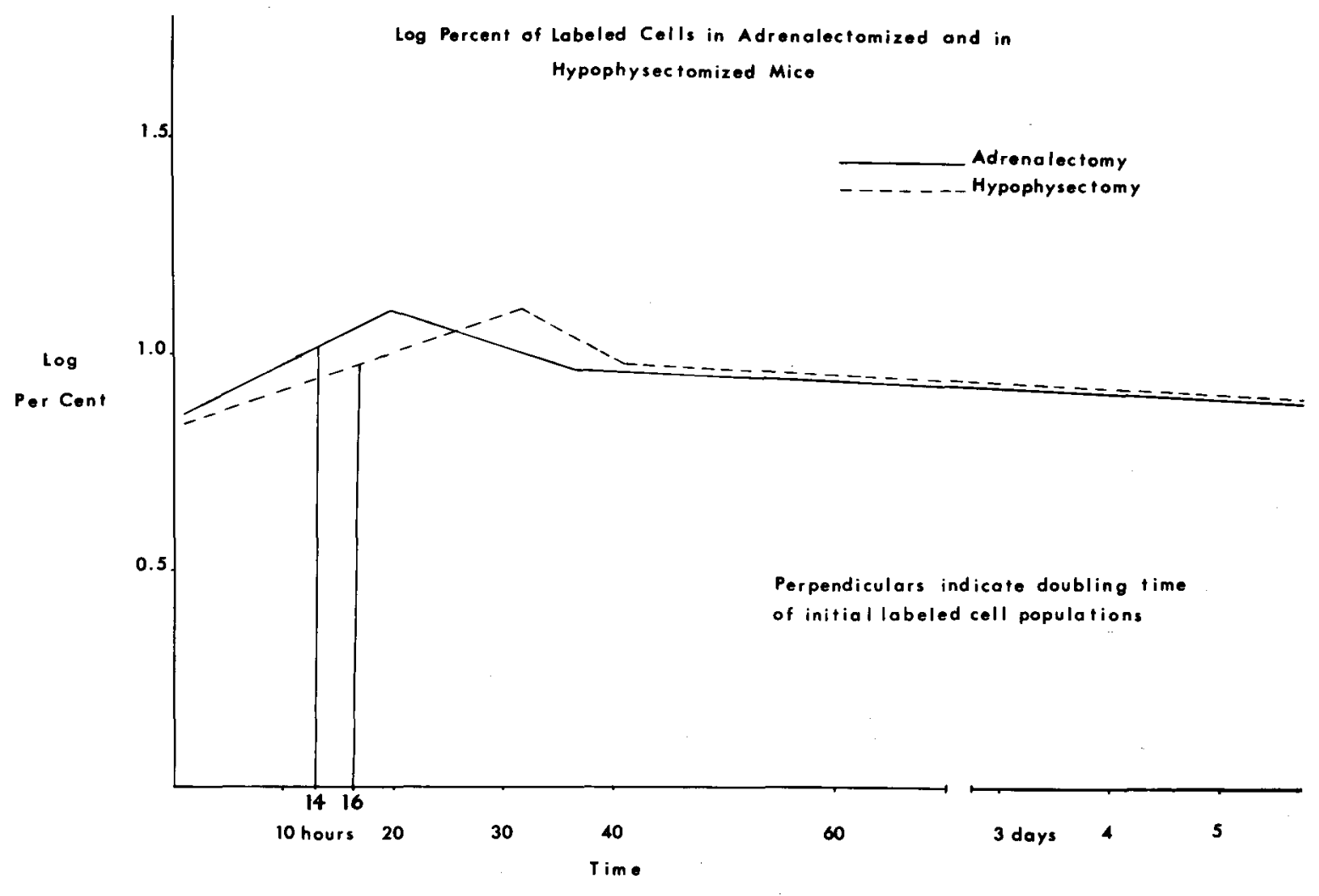


F1 gure 3. One hour sperinon adrenclectoulzed mouse interdental papilin eutoradionram stalned wh nooloar fast red and indigo candme. OMginal angnifioation X25. 


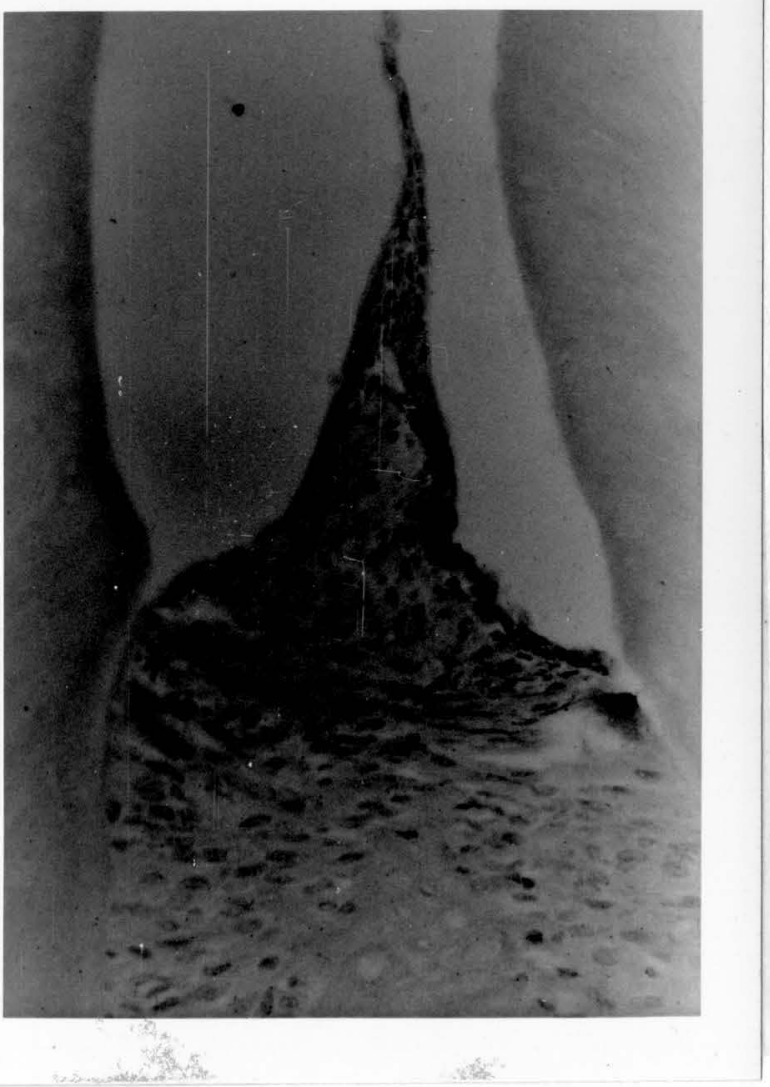


Figure 4. Fourteen hour specimen adrenlectomized mouse interdental papilla autoradiogram stained with nuclear fast rod and indigo carmine. Original]. magnification X25.

49 


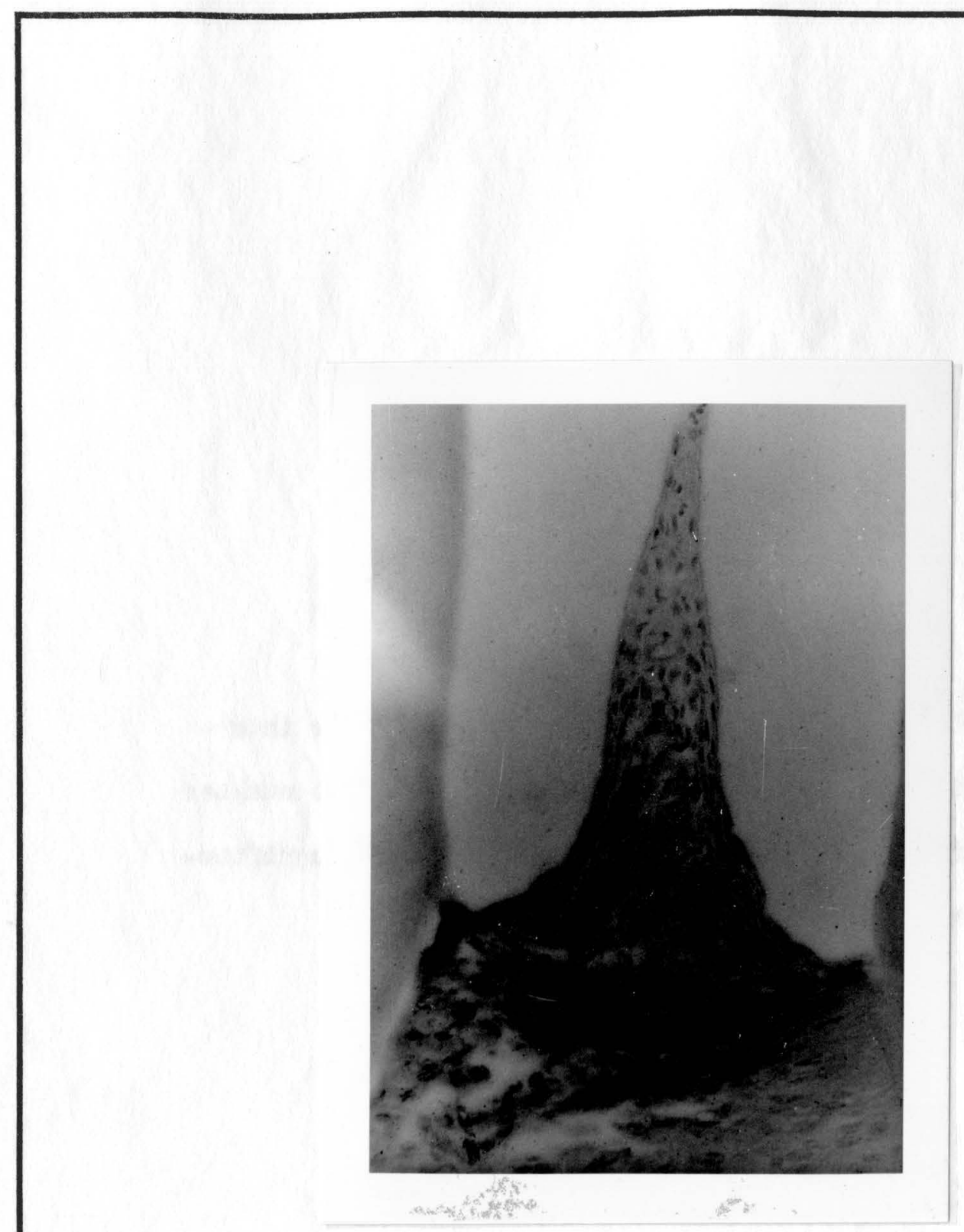


FIgure 5. One hour specimen hypophysectomized mouse interdental papilla autoradlogran stained with nuelour fast rod and indigo carmine. Original magrifloaLion X25.

50 


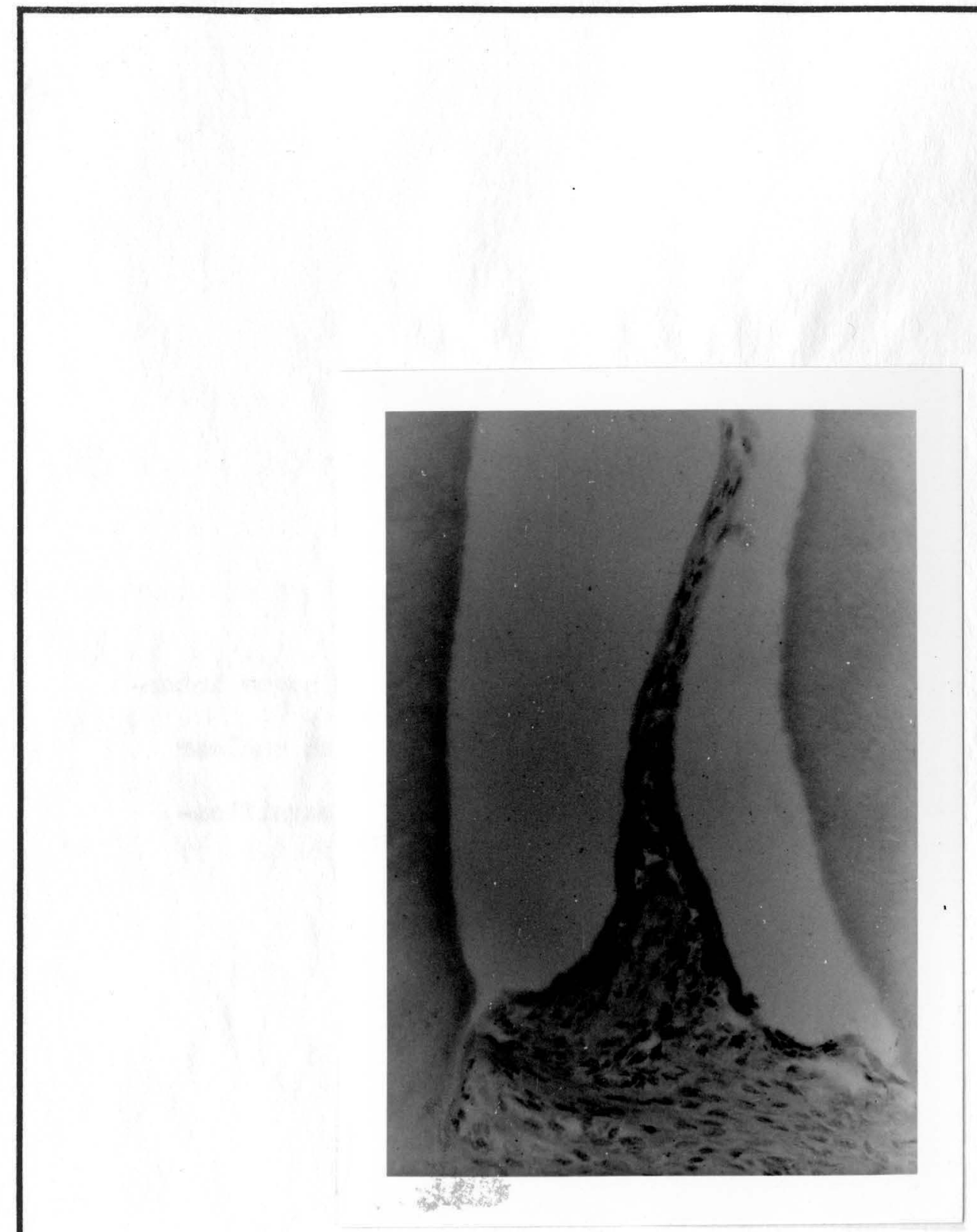


Figure 6. Sixteen hour specimen hypophysectomized mouse interdental papilla autorediogram stained with nuclear fest red and indigo carmine. Original magnification $\times 25$. 


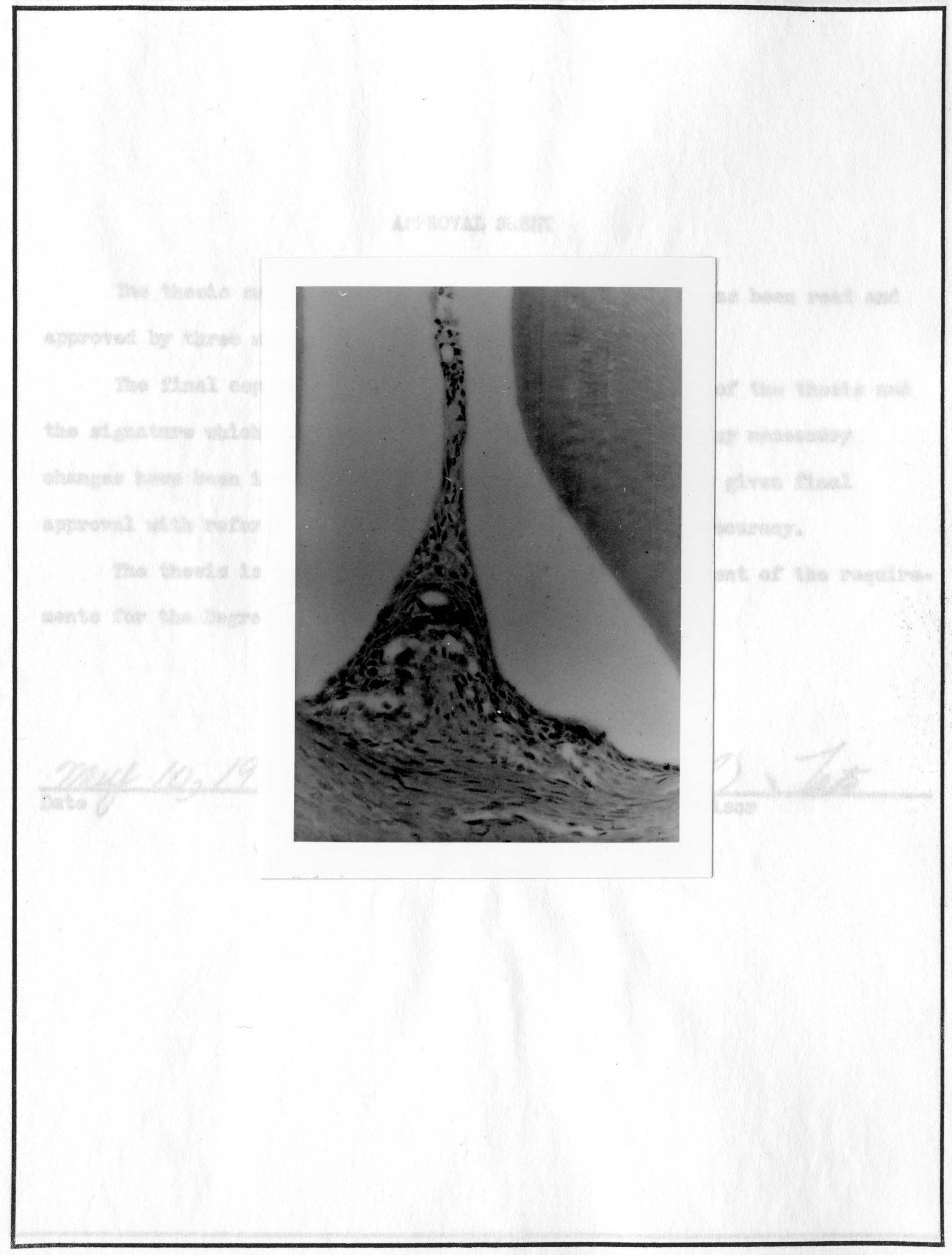




\section{AFPROVAL SHEET}

The theals subuitted by Dr. Elllott Howard DLokler has been read and epproved by three nembers of the Graduate School Paculty.

The final coples have been exanined by the direotor of the thests and the Agnature whioh appeare below verifles the faot that any necessary changes have been inoorporated, and that the theals is now given final approval with reforence to contont, form, and mechanical acouracy.

The thesis is thorefore acoopted in partial rulfilinont of the requirenents for the Degree of Master of Botence.
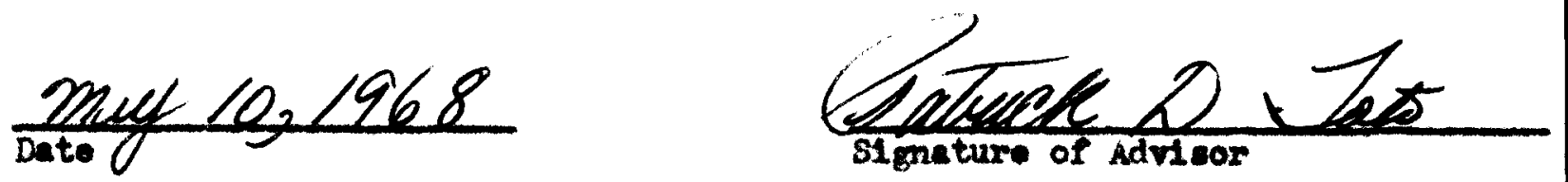